RADOVI

UDK 351.755.3:336.22(497.523Varaždin)“16“

Zavoda za znanstveni rad

Izvorni znanstveni članak

HAZU Varaždin

Original Scientific Paper

VIŠNJA BUREK

Primljeno: 05. 10. 2020.

Varaždin

Prihvaćeno: 20.11.2020.

vburek@yahoo.com

DOI: $10.21857 / 94 \mathrm{kl} 4 \mathrm{czg} 2 \mathrm{~m}$

\title{
POPISI VLASNIKA GRADSKIH ZEMLJIŠTA U VARAŽDINU IZ DRUGE POLOVICE 17. STOLJEĆA
}

Gradska uprava u Varaždinu sastavljala je popise vlasnika fundusa za potrebe ubiranja redovnih i izvanrednih poreza i gradskih pristojbi. Iz druge polovice 17. stoljeća sačuvano je deset popisa od kojih je posljednji, iz 1698. godine, cjelovit, a ostali se odnose na pojedine gradske četvrti. Popisi također donose informacije o broju fundusa koje su posjedovali isusovci, pavlini, prelati, Varaždinski generalat i tridesetnica koji su, kao vlasnici gradskih zemljišta, također bili obavezni plaćati poreze. Porez se plaćao prema veličini fundusa.

Analiza prosječne veličine posjeda potvrđuje da su tijekom druge polovice 17. stoljeća povećane ekonomske i socijalne razlike unutar gradskog društva. Stanovnici unutrašnjeg grada posjedovali su prosječno 1,5 - 2 fundusa, a u suburbijima 1,1 - 1,4. Na prosječnu veličinu posjeda utjecali su vlasnici većeg broja fundusa, samostani, Crkva, vojne i civilne službe Kraljevine, čiji broj fundusa raste posebno u unutrašnjem gradu. Oni posjeduju više od 20 posto gradskog zemljišta. Najveći pojedinačni vlasnici su isusovce. Većim brojem fundusa raspolažu također suci, senatori te plemstvo. U suburbijima pratimo suprotan proces, umjesto povećanja, postojeći fundusi se dijele na sve manje čestice. To je pokazatelj veće gustoće stanovanja u suburbijima, ali i sve većeg broja siromašnih građana čija je ekonomska snaga u padu.

Uz analizu ekonomskih i socijalnih procesa u gradu popisi su izvor za procjenu broja stanovnika Varaždina krajem 17. stoljeća. Na temelju broja nastanjenih fundusa i prosječnog broja ukućana procijenjeno je da je krajem 17. stoljeća u gradu živjelo između 2850 i 3350 stanovnika. Popisi sadrže, uz ime i veličinu fundusa, informacije o smještaju, vrsti, kvaliteti zemljišta i iznosu plaćenog poreza ili pristojbe te je važan izvor za povijest katastra grada Varaždina.

Ključne riječi: popisi građana; Varaždin; fundus; porezi; 17. stoljeće. 


\section{UVOD}

Cjeloviti popisi stanovništva i prikupljanje podataka o demografskim promjenama, ekonomskim aktivnostima, socijalnoj, nacionalnoj i rodnoj strukturi počinju se provoditi razvojem građanskih država u 19. stoljeću. Međutim, informacije o popisivanju određenog dijela populacije s namjerom da se prikupe određeni podaci sežu daleko u povijest. Oni su najčešće u funkciji skupljanja poreza i drugih davanja u kojima se popisuju nositelji tih obaveza. Popisuju se i vojni obveznici za potrebe novačenja i popunjavanja vojske ili isplate plaća. Popise svojih članova vodili su cehovi, a gradske uprave popise izabranih ili imenovanih službenika i članova skupštine te popise osoba određenih zanimanja, npr. trgovaca, obrtnika, stranaca i sl. Crkvene vizitacije i matične knjige također su važan izvor informacija o stanovništvu nekog područja. Međutim, vođenje matičnih knjiga krštenih (rođenih), vjenčanih i umrlih postala je obaveza župnika tek nakon Tridentskog koncila. One pomažu u prikupljanju podataka o stanovništvu na relativno malom području župe, a njihova vrijednost kao povijesnog izvora ovisi o kontinuitetu vođenja i njihovoj očuvanosti. U kontinentalnoj Hrvatskoj malo je sačuvanih matičnih knjiga iz razdoblja prije 18. stoljeća. Popisivače, način popisivanja i informacije koje se prikupljaju određivali su korisnici informacija, upravna tijela svjetovne ili crkvene vlasti.

Za povijest slavonskih gradova, trgovišta i naselja u ranom novom vijeku poseban značaj imaju popisi kućedomaćina ili vlasnika kuća i zemljišta nastali za potrebe novačenja vojnika, ubiranje poreza i lukna. Dok su u jednima poimenično popisani vlasnici, u drugima se sumarno navodi ukupni broj kuća i stanovnika. U hrvatskoj historiografiji oni se najčešće koriste kao sekundarni izvor na temelju kojeg se prate demografska kretanja i procjenjuje broj stanovnika pa se u objavljenim radovima uglavnom analizira njihov broj. Iz druge polovice 17. stoljeća sačuvani su popisi obveznika davanja lukna u župama komarničkog arhiđakonata nastali tijekom vizitacija 1659., 1671. i 1680. godine. U njima se nalaze i popisi kućedomaćina u koprivničkoj župi. Popise je, u svrhu procjene broja stanovnika u župama komarničkog arhiđakonata, Podravini i Koprivnici u više članaka analizirao Stjepan Krivošić. ${ }^{1} \mathrm{U}$ novije vrijeme naseljima i stanovništvom u slavonskim gradovima u ranom novom vijeku bavi se Hrvoje Petrić. ${ }^{2}$

1 Stjepan KRIVOŠIĆ, „Stanovništvo Podravine 1659. - 1859. godine“, Podravski zbornik, No. 9., 1983., 147-165 i Stjepan KRIVOŠIĆ, „Koprivnica - naselje i njegovi stanovnici: od sredine XVII. do sredine XIX. stoljeća", Podravski zbornik, No. 14., 1988., 120-140.

2 Hrvoje PETRIĆ, Pogranična društva i okoliš; Varaždinski generalat i Križevačka županija u 17. stoljeću, Meridijani i Društvo za hrvatsku ekonomsku povijest i ekohistoriju, Samobor - Zagreb, 2012. i Hrvoje 
Upravna autonomija Varaždina kao slobodnog kraljevskog grada podrazumijevala je obavljanje različitih poslova upravljanja Gradom, njegovom imovinom kao i obavljanje upravnih poslova i izvršavanje odluka viših upravnih tijela, varaždinskog župana, Hrvatskog sabora i kralja. Od poslova i naredbi viših tijela upravne vlasti u 17. stoljeću svakako je najvažniji posao bio skupljanje redovnih i izvanrednih poreza te gradskih pristojbi. Građani su također bili obavezni na različita davanja u obliku radova ili dovoza materijala, na primjer dovoz kamenja za popravak gradskih ulica ili obnovu župne crkve, te su se popisima određivale obaveze. Osnova za razrez poreza bio je fundus (grunt), odnosno gradsko zemljište s kućom, gospodarskim zgradama ili bez njih. Izvori ne donose informacije o veličini fundusa iako je ona bila određena, što potvrđuju popisi u kojima se navode vlasnici cijelih fundusa, polovice ili tek čestice. Vijesti o parcelaciji gradskog zemljišta u Varaždinu sežu u 13. stoljeće. Prema povelji kralja Andrije II. iz 1209. godine građani su dužni plaćati županu 12 denara od svakog gradskog zemljišta, ${ }^{3}$ ali nepoznato je na koji je način provedena parcelacija. Razrezivanje poreza, gradskih pristojbi i drugih obaveza građana prema broju i veličini fundusu zahtijevalo je popisivanje njihovih vlasnika i stalno ažuriranje popisa.

Najstariji poznati popis građana Varaždina je popis iz oko 1520. godine koji se čuva u Državnom arhivu u Nürnbergu u arhivskom gradivu obitelji Brandenburg. Nastao je za potrebe ubiranja poreza tadašnjeg vlasnika varaždinske tvrđe Jurja Brandenburga. ${ }^{4}$ Popis donosi imena 100 vlasnika kuća u unutrašnjem gradu i 250 u suburbijima navodeći ponegdje uz ime vlasnika i njegovo obrtničko zanimanje. ${ }^{5}$ Slijedeći sačuvan popis iz 16 . stoljeća nastao je 1566 . godine za potrebe ubiranja kraljevskog poreza po jednakom obrascu kao i popis iz 1520. godine. Ukupni broj vlasnika kuća u gradu bio je 256 , od toga 130 u unutrašnjem gradu. ${ }^{6}$ Navedene popise historičari najčešće koriste kao polazište za procjenu broja stanovnika u Varaždinu u 16. stoljeću.

PETRIĆ, Koprivnica u 17. stoljeću: okoliš, demografske, društvene i gospodarske promjene u pograničnom gradu, Samobor, Meridijani, 2005.

3 Statuta civitatis Varasdiensis, preveli i priredili Josip KOLANOVIĆ i Mate KRIŽMAN, Državni arhiv u Varaždinu, Varaždin, 2001., 53.

4 Neven BUDAK, Gradovi varaždinske županije u srednjem vijeku, Nakladna kuća dr. Feletar, Koprivnica, 1994., 158.

5 Popis je objavila Ljerka Perči. Ljerka PERČl, „Popis građana Varaždina iz 1520. godine“, Radovi Zavoda za znanstveni rad Varaždin, No. 1, Zavod za znanstveni rad HAZU Varaždin, Zagreb-Varaždin, 1986., 267-275.

6 BUDAK, n. dj., 160. 
VIŠNJA BUREK: Popisi vlasnika gradskih zemljišta u Varaždinu iz druge polovice 17. stoljeća

\section{POPISI VLASNIKA FUNDUSA DRUGE POLOVICE 17. STOLJEĆA}

Popisi vlasnika fundusa iz druge polovice 17. stoljeća, koji su tema ovog rada, nalaze se u Radikalnom arhivu fonda br. 2 Poglavarstva slobodnog i kraljevskog grada Varaždina od kojih se jedan popis iz 1670. i dva popisa iz 1673. godine nalaze među ispravama i spisima, a popisi iz 1668., 1669., 1673., 1688., 1689.?, 1695. i 1698. godine u svežnju "Računi kmetskog suca i tržnog nadzorništva 1632. - 1784. godine". Popis u Radikalnom arhivu iz 1670. te dva popisa iz 1673. godine dobro su očuvana, na kvalitetnom su papiru i pisana lijepim i čitkim rukopisom, dok su popisi u svežnju na papiru slabije kvalitete, oštećenih rubova i ponegdje teško čitljivi. ${ }^{7}$ Listovi su povezani u knjižice, a na naslovnici je navedeno ime i služba popisivača izabranog od suca i senatora te godina popisa. Sačuvani popisi su zapravo prijepisi na latinskom jeziku koje su napravili bilježnici i zaključili ih potpisom. Na to upućuje razlika u kvaliteti rukopisa popisa i izvještaja na kraju knjižice, koji je popisivač zapisao vlastoručno, o izdacima novca za potrebe popisivanja i o količini novca predanog sucu. Izvještaj je pisan neujednačenim rukopisom i na kajkavštini.

Od deset popisa samo se posljednji iz 1698. godine može smatrati cjelovitim. Ostali obuhvaćaju unutrašnji grad ili dio unutrašnjeg grada i jednog od gradskih suburbija ili samo suburbije. Međutim, i nepotpuni popisi daju kvalitetne informacije o gradu i stanovnicima. Druga polovica 17. stoljeća razdoblje je u kojem je završena izgradnja franjevačkog i isusovačkog kompleksa sa školom i sjemeništem te je urbana struktura unutrašnjeg grada dobila obris koji je sačuvala do danas. Uz to, popisi su nastali nakon velikog požara 1665. godine u kojem je stradao veliki dio grada te se popisima može pratiti tijek obnove nakon njega i promjene nastale novom izgradnjom. Spojeni su neki fundusi na kojima su izgorjele kuće i na njima su izgrađene nove i veće, posebno u unutrašnjem gradu i uz ophodnu cestu oko obrambenog jarka. Uz teške posljedice koje je ostavio požar, druga polovica 17. stoljeća razdoblje je vertikalnog raslojavanja gradskog društva. ${ }^{8}$ Kako su popisani svi fundusi koje su građani posjedovali u unutrašnjem gradu ili suburbijima kao i vrsta fundusa, prazan, alodij ili vrt, popisi omogućuju analizu strukture gradskog posjeda i socijalni status vlasnika. Popisi donose također i informacije o broju fundusa koje su posjedovali isusovci, pavlini, prelati, Varaždinski generalat i tridesetnica koji su, kao vlasnici gradskih zemljišta, ta-

HR-DAVŽ-2. Poglavarstvo grada Varaždina, Radikalni arhiv, Računi kmetskog suca i tržnog nadzorništva 1632. - 1784. (dalje: PGV, R. a., Računi kmetskog suca).

8 O društvenim borbama u gradu vidi više u: Višnja BUREK, Otkrivanje gradskih tajni; Varaždin u 17. stoljeću, HAZU Zavod za znanstveni rad u Varaždinu, Zagreb - Varaždin, 2019., 339-419. 
kođer bili obavezni plaćati poreze. Posjedovanje većeg broja fundusa pojedinih vlasnika nije utjecalo na promjenu ubiranja poreza koji se i dalje plaćao zasebno za svaki fundus. Zapisnici poglavarstva grada Varaždina (dalje Protokoli) zabilježili su probleme u prikupljanju poreza tijekom cijelog 17. stoljeća. U zaključku senata iz 1599. godine o povećanju redovnog poreza navodi se da se ni jedne godine nije moglo prikupiti dovoljno novca za podmirenje miholjčice ${ }^{9}$ koja je iznosila $160 \mathrm{fl}^{10}$ te je gradski oficijal ${ }^{11}$ uvijek morao dodati 40 - $50 \mathrm{fl}$ iz gradske blagajne. Zbog toga je bilo potrebno povećati porez. Određeni su građani koji će izvršiti reviziju fundusa unutar i izvan bedema te će se na temelju broja fundusa razrezati porez. ${ }^{12}$ Problemi su posebno izraženi u drugoj polovici 17. stoljeća kad su stanovnici grada postali pripadnici svjetovnog i vojničkog plemstva koji su svoje plemićke povlastice neplaćanja poreza primjenjivali i na gradska zemljišta. U to vrijeme učestali su sudski postupci protiv neplatiša kao i žalbe kralju i zapovjednicima Varaždinskog generalata (dalje: Generalat). ${ }^{13}$

Vlasnici fundusa popisivali su se prema gradskim četvrtima u kojima su živjeli. Od kraja 16. do kraja 17. stoljeća grad je bio podijeljen na četiri gradske četvrti. Unutrašnji grad, zaštićen bedemima i obrambenim jarkom, nije bio zasebna četvrt, već je podijeljen i povezan s dijelovima suburbija. Potkraj 17. stoljeća provedena je teritorijalna reorganizacija i uvedena podjela na tri četvrti. Popisivači fundusa bili su četvrtari ${ }^{14}$ ili drugi građani koje bi izabrali sudac i senat. Sačuvani popisi ukazuju na to da se vlasništvo provjeravalo prema starijim predlošcima. Na nekim mjestima precrtano je ime starog vlasnika i upisano novo. Uz to, imena nekih vlasnika zadržana su i nakon prodaje kuće ili zemljišta, što potvrđuju kupoprodajni ugovori zapisani u Protokolima. Ako su zemljišta bila založena, porez su plaćale osobe koje su ih držale u zalogu.

Od deset popisa iz druge polovice 17. stoljeća samo je za popise iz 1695 . i 1698. godine na naslovnici knjižice naveden razlog popisivanja, skupljanje novca za popravak gradskih mostova. Međutim, računi mesarskog ceha pokazuju kojim

9 Miholjčica je bio prihod varaždinskog župana koju je Grad podmirivao na da sv. Mihaela po kojem je dobila i ime (op. a.).

10 Florenus Hungaricalis (ugarska forinta).

11 Oficijal (officialis bonorum civitatis, sodecz, officialis colonorum) bio je gradski službenik koji je vodio brigu o gradskim dobrima, vinogradima, poljima, šumama, sjenokošama i upravljao gradskim kmetovima (op. a).

12 Zapisnici poglavarstva grada Varaždina (dalje: ZPGV, broj sveska, godina, stranica u ediciji), ur. Josip BARBARIĆ, svesci I - XI, Državni arhiv u Varaždinu, Varaždin, 1990. do 2006., III/1599., 198.

13 O problemu ubiranja poreza od gradskih zemljišta vidi više u: BUREK, n. dj., 56-58.

14 Četvrtari su bili izabrani gradski službenici koji su obavljali različite poslove na temelju odluka suca i senata u četvrti za koju su izabrani. Više o četvrtarima vidi u: BUREK, n. dj. 235-236. 
su porezima i pristojbama bili opterećeni vlasnici zemljišta. Mesari su imali dva zemljišta u unutrašnjem gradu u Školskoj ulici te u izdacima ceha navode isplate za poreze i pristojbe. ${ }^{15}$ Najčešće se spominju miholjska i martinska daća. Nekoliko puta se spominje kraljevica, a u vrijeme ratova i soldački penezi. Mesari su 1686. godine platili miholszke daće od nuterniega grunta czesskoga 20 denara, martinszke dachae od toga grunta 80 denara, szoldaczkeh penez od grunta toga opervich 80 denara i drugoch od toga grunta szoldaczkeh penez forintu i 20 denara. ${ }^{16}$ Sedam godina kasnije, 1693 . godine, platili su od cheskoga grunta portiae dvije forinte i 40 denara, miholizke dache od grunta cheskoga 20 denara, od cheskoga grunta szoldaczkeh penez 80 denara i martinszke dache 80 denara. ${ }^{17}$

\section{POPISI IZ 1668. I 1669. GODINE}

U popisima iz 1668. i 1669. godine popisani su vlasnici zemljišta druge gradske četvrti koja je obuhvaćala sjeverni i sjeveroistočni dio unutrašnjeg grada, Gajevu, Kukuljevićevu, Usku i nestalu uličicu uz istočni gradski bedem (Mesnička ulica) te Ciglenicu i Brodovski konec (danas Trstenjakova i Trenkova ulica) u sjevernom suburbiju. ${ }^{18}$ Sjevernom suburbiju pripadao je i Dravički konec (danas Starčevićeva ulica) kao i kuće uz sjeverni obrambeni jarak. Kako u popisu vlasnika kuća u Brodovskom koncu i u Ciglenici nalazimo i one čije kuće Protokoli lociraju u Dravički konec ili uz obrambeni jarak, možemo zaključiti da je popisom obuhvaćen veći dio sjevernog suburbija. Popisom nisu obuhvaćena zemljišta i alodiji isusovaca.

15 Cehmeštar zapisuje u Knjigu računa da je platio od fundussa vu Varassu dache martinszke i miholszke dacse od gruntou ceskeh. Usp. Krešimir FILIĆ, Varaždinski mesarski ceh, Kulturno-prosvjetno vijeće općine Varaždin, Varaždin, 1968., 312, 229.

16 FILIĆ, n. dj., 315.

17 Isto, 346-347.

18 PGV, R. a., Računi kmetskog suca. 
U dvama navedenim popisima koje je potpisao, a prema rukopisu i sastavio bilježnik Andrija Husz, nema značajnijih razlika. U dijelu unutrašnjeg grada popisano je 63 (61) fundusa i 45 (46) vlasnika. Popisana su četiri (dva) vrta i deset zapuštenih zemljišta, od toga šest u Velikoj (Gajevoj) ulici koja je teško stradala u požaru 1665. godine. U Brodovskom koncu i Ciglenici popisano je 148 (143) građana koji su vlasnici 155 (156) fundusa od čega 44 u Ciglenici i 111 (112) u Brodovskom koncu. U popisu su četiri vrta i četiri zapuštena zemljišta. Zanimljivost popisa su tri fundusa u Brodovskom koncu na kojima su se nalazile mesnice. ${ }^{19}$

Većina građana vlasnici su jednog fundusa, ali u popisima se izdvajaju tri koji posjeduju više fundusa u unutrašnjem gradu i suburbijima. Najveći je posjednik plemić Stjepan Peršinović, aulae familiaris zagrebačkog biskupa Petra Petretića, priženjen u trgovačku obitelj Gonan, sa šest zemljišta u unutrašnjem gradu i alodijem u suburbiju. Fundusi, od kojih se za dva navodi da su zapušteni, mogu se locirati u Gajevu ulicu pa se vjerojatno radi o zemljištima koje je Peršinović uzeo u zalog za posuđeni novac vlasnicima čije su kuće izgorjele ili oštećene u požaru. Brojem fundusa izdvaja se Ivan Kristofor Bosserman (Wasserman), kaštelan varaždinske tvrđe, koji je posjedovao tri fundusa u unutrašnjem gradu nasuprot vrata tvrđe na kojima je podigao zidanu kuću (kasnije palača Sermage). Posjedovao je i vrt uz sjeveroistočni obrambeni jarak i staje Generalata (Padovčeva ulica) te dva alodija u suburbiju. Licitar Matija Rainstrom vlasnik je dvaju fundusa i vrta u unutrašnjem gradu i alodija u Brodovskom koncu.

U obama popisima naveden je i plaćeni iznos za svako zemljište, 60 denara za funduse u unutrašnjem gradu, a 30 u suburbijima, međutim, na naslovnici knjižice nije navedena vrsta poreza ili pristojbe koja se prikupljala. Prema računima mesarskog ceha, martinska i miholjska daća bile su nepromijenjene od 1652. godine do kraja stoljeća, miholjska daća iznosila je 20 denara, a martinska 80, dok se iznos kraljevice i soldačkih peneza mijenjao i uglavnom je bio viši od 80 denara. ${ }^{20}$ Preostaje porez od posesiae od ceskeh gruntov ili od cheskoga grunta portiae, pristojbe za posjedovanje gradskog zemljišta koja se mijenjala u skladu s odlukama magistrata. Već 1670 . godine povišena je na 80 denara za unutrašnja i 40 denara za vanjska zemljišta.

19 Tablični prikaz svih popisa nalazi se dalje u tekstu (op. a.).

20 Mesari su za kraljevicu 1655. platili 50 denara, 1659. 2 forinte. Soldačkih peneza dali su $1663.1 \mathrm{fl}$ 60 denara, 1684. 1 dukat i 20 denara, a 1693. godine 80 denara. Usp. FILIĆ, n. dj., 230, 241, 252, 312, 347. 


\section{POPISI IZ 1670. GODINE}

Popis četvrte četvrti iz 1670. godine također je sastavio i potpisao bilježnik Andrija Husz. Četvrta četvrt obuhvaćala je jugozapadni dio unutrašnjeg grada, zapadni dio današnje Gundulićeve ulice, južnu stranu Franjevačkog trga, Uršulinsku ulicu, Ulicu sv. Nikole (Draškovićeva ulica) s uličicom mesara (Školska ulica) i kuće uz Donja vrata. Unutrašnjem gradu pridružen je Dugi konec (Zagrebačka ulica) u južnom suburbiju. ${ }^{21}$ Međutim, u popisu vlasnika kuća i zemljišta u Dugom koncu nalaze se vlasnici u Vidovskom koncu (Blažekova ulica), Cargovcu (Ulica Frana Supila) i južnom dijelu ophodne ceste oko obrambenog jarka, što se može potvrditi kupoprodajnim ugovorima u Protokolima.

Zapadni dio unutrašnjeg grada bio je slabije urbaniziran. Uz zapadni bedem, prema Protokolima, još je uvijek bilo praznih zemljišta i vrtova, ali popisivač ih nije označio u popisu. Broj fundusa manji je od sjevernog dijela grada, u popisu je 27 vlasnika koji posjeduju 45 fundusa. U toj četvrti nalazilo se pet fundusa u vlasništvu Generalata na kojima se nalazila kuća - stan zapovjednika Slavonske krajine, ${ }^{22}$ tri fundusa u vlasništvu Zagrebačkog kaptola (Uršulinska ulica) stečena 1661. godine legatom Ivana Vojkovića od Klokoča ${ }^{23}$ te zgrada varaždinske tridesetnice sa stajama uz zapadni bedem. U južnom suburbiju popisano je 86 fundusa u vlasništvu sedamdesetčetvorice građana. Uz Generalat najveći pojedinačni vlasnik fundusa bio je Ludovik Šavor, konjanik varaždinske regimente, koji je posjedovao četiri zemljišta u unutrašnjem gradu. Njegovo vlasništvo bila je kuća na uglu Draškovićeve i Kačićeve ulice ${ }^{24}$ sa zemljištem koje se protezalo do zapadnog gradskog bedema. Šavor je posjedovao i alodij u suburbiju.

\section{POPISI IZ 1673. GODINE}

Zbog brojnih promjena vlasništva i poteškoća u skupljanju poreza i pristojbi magistrat je odlučio da se napravi novi popis fundusa. Uz požar i prodaju opožarenih zemljišta značajan broj kuća i zemljišta došao je legatima u posjed Crkve i crkvenih redova koji su kao novi vlasnici bili obavezni na plaćanje svih poreza

21 PGV, R. a., 952 XLVI-745.

22 Kuća Varaždinskog generalata nalazila se na mjestu današnje zgrade Varaždinske županije na Franjevačkom trgu. Zemljište Generalata protezalo se do Školske ulice (op. a.).

23 ZPGV, VII/1661., 153.

24 Kuća se nalazila na mjestu na kojem je u 18. stoljeću izgrađena barokna palača Zagrebačkog kaptola (op. a.). 
i pristojbi kao i građani. ${ }^{25}$ Tome su se posebno opirali isusovci, o čemu svjedoče isprave Radikalnog arhiva o sudskim sporovima Grada i isusovaca. Sačuvana su tri popisa, dva koja popisuju vlasnike fundusa u unutrašnjem gradu i jedan $\mathrm{s}$ popisima vlasnika u sjevernom suburbiju. Sva tri popisa sastavio je i potpisao bilježnik Andrija Husz.

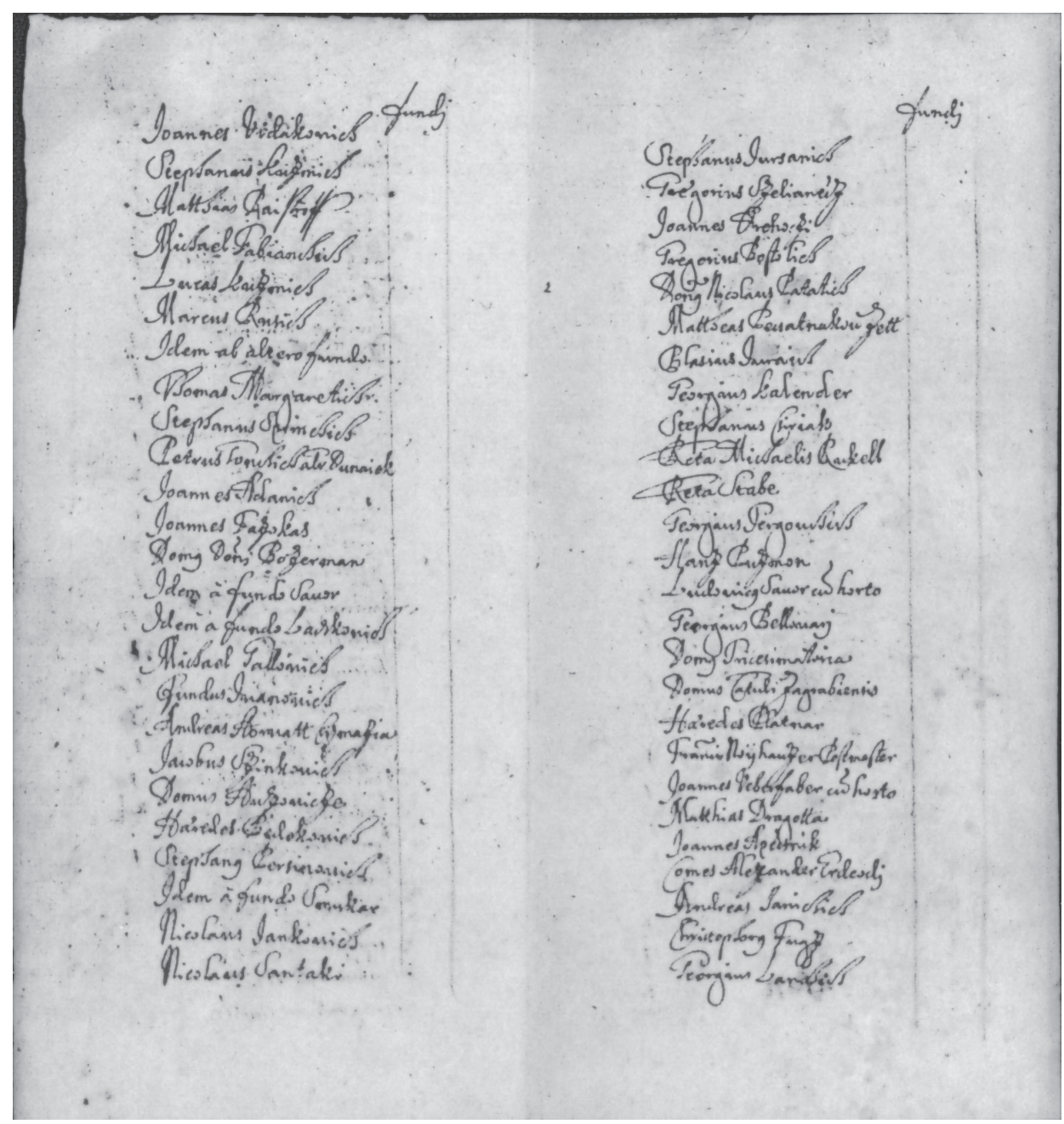

Slika 1. Popis vlasnika fundusa u unutrašnjem gradu iz 1673. godine, PGV, R. a., 953 XLVI-746.

25 Franjevci su bili izuzeti od plaćanja poreza i gradskih pristojbi osim za zemljište na kojem su se nalazile staje i vrt (op. a.). 
U prvom popisu unutrašnjeg grada popisano je 105 fundusa i 92 vlasnika, ali rubrika u koju je trebalo upisati broj i veličinu fundusa ostala je dijelom prazna pa je ukupan broj fundusa nepoznat. Nedostaju podaci za zemljišta isusovaca kao i značajnog dijela vlasnika zemljišta u Gajevoj, Gundulićevoj ulici te Franjevačkom trgu koja se mogu dokumentirati Protokolima ${ }^{26}$ Drugi popis je detaljniji, 69 vlasnika posjedovalo je 127 fundusa. Uz ime vlasnika i veličinu fundusa upisan je i iznos plaćenog poreza, 80 denara za zemljište u unutrašnjem gradu. ${ }^{27}$

$\mathrm{Ni}$ drugi popis ne sadrži imena svih vlasnika, međutim, dva popisa se međusobno nadopunjuju. Njihovim objedinjavanjem dolazimo do brojke od 181 fundusa i 127 vlasnika. U cijelosti su popisana zemljišta na kojima su izgrađeni isusovački samostan, crkva, škola i sjemenište s imenima vlasnika od kojih su isusovci kupili zemljišta za gradnju. Samostanski kompleks zauzimao je 12 fundusa, a sjemenište šest. Generalat je posjedovao osam zemljišta na kojima se nalazio stan zapovjednika na Franjevačkom trgu i staje u Padovčevoj ulici. Uz tri zemljišta Zagrebačkog kaptola u Uršulinskoj ulici zagrebački biskup posjedovao je kuću na glavnom trgu kupljenu od nasljednika plemića Jurja Šambara. ${ }^{28} \mathrm{Uz}$ isusovce i Generalat vlasnici triju i više zemljišta već su spomenuti pripadnici vojničkog plemstva, kaštelan tvrđe Ivan Kristofor Bosserman, zapovjednik konjaništva Ludovik Šavor, vojnik Ivan Lochenperger i Draškovići.

Vlasnike zemljišta i kuća gornjeg suburbija popisao je četvrtar druge četvrti Juraj. Naslovnica knjižice donosi informaciju da će Juraj popisati gornji (donji je precrtano) dio vanjskog grada. Međutim, u knjižici su dva popisa između kojih postoje značajne razlike. U prvom dijelu, bez opisa o kojem se dijelu grada radi, popisano je 133 vlasnika i 139 funudsa, ali bez informacija o broju i veličini zemljišta, praznim zemljištima ili vrtovima. Prema kupoprodajnim ugovorima u Protokolima može se zaključiti da su popisani vlasnici fundusa u Brodovskom koncu i sjevernom dijelu ceste oko obrambenog jarka. Drugi dio, u kojem je naznačeno da se radi o vlasnicima gornjeg vanjskog grada, obuhvaća vlasnike Miličkog konca, Slopanca, Dravičkog konca, Ciglenice i Rogoznice sve do Dravice, s obzirom na to da su uključena dva mlina, Mihaela Vukšića i isusovaca. Popisano je 87 vlasnika, ali rubrika o broju fundusa ostala je prazna. ${ }^{29}$ Objedinjavanjem jednog i drugog fundusa kojim je obuhvaćen cijeli sjeverni i sjeverozapadni dio vanjskog grada, dolazimo do 200 vlasnika, ali bez točnih informacija o broju i ve-

26 PGV, R. a., 953 XLVI-746.

27 PGV, R. a., Računi kmetskog suca.

28 ZPGV, VII/1666., 299-301.

29 PGV, R. a., 954 XLVI-747. 
ličini fundusa. Zanimljivost popisa je, uz tri mesnice, zanimanje jednog vlasnika: Jakoba vertara, kojeg u popisu iz 1688. godine zovu Jakob hortulanus (vrtlar). Zanimanje vrtlar spominje se u Gradskim knjigama iz sredine 15. stoljeća, ali do ovog popisa u izvorima nema vijesti o tom zanimanju u gradu. Vrtlar je vjerojatno bio u službi obitelji Drašković s obzirom na to da je nakon njegove smrti fundus pripao Draškovićima.

\section{POPIS IZ 1688. GODINE}

Iz 1688. godine sačuvan je popis vlasnika druge četvrti, odnosno gornjeg suburbija o plaćanju poreza koji je iznosio, kao i 1670. godine, 40 denara za zemljišta u suburbiju. U popisu je popisano više od 300 fundusa, međutim, imena vlasnika su teško čitljiva zbog oštećenja i izblijedjele tinte. U svežnju se nalazi još jedan nepotpun i nedatiran popis vlasnika fundusa u sjevernom suburbiju. Prema potpisu bilježnika Matije Petrovića može se datirati u vrijeme kad je Petrović obnašao bilježničku službu, tj. od 1689. do 1693. godine. ${ }^{30}$

\section{POPIS IZ 1695. GODINE}

Popis iz 1695. godine imao je drukčiju funkciju, bio je sastavljen za potrebe skupljanja sredstava za popravak gradskih mostova po nalogu Kraljevstva, kako je zapisano na naslovnici knjižice. Hrvatski sabor je tijekom 17. stoljeća nekoliko puta raspravljao o stanju gradskih bedema i potrebi čišćenja obrambenog jarka. Sa Sabora u Zagrebu 1655. godine stigao je nalog Varaždinu da popravi gradski zid. Popravak jugoistočnog dijela gradskog bedema obavio je zidar Štef Kasar 1659. godine. ${ }^{31}$ Dvije godine kasnije, 1661 . godine, gradski zidari Blaž Hoheneker i Jakob Jančić popravljali su gradske bedeme s vanjske strane od temelja do sredine tornjeva. ${ }^{32}$ Mostovi preko obrambenog jarka kod Gornjih i Donjih gradskih vrata bili su dio fortifikacijskog sustava Varaždina koje je također trebalo popravljati. To nisu bili jedini mostovi o kojima je brigu vodio Grad. Izvori iz 17. stoljeća spominju most preko kanala kojim je Dravica utjecala u obrambeni jarak

\footnotetext{
30 PGV, R. a., Računi kmetskog suca.

31 ZPGV, VI/1659., 420.

32 PGV, R. a., 444 XXIX-240.
} 
VIŠNJA BUREK: Popisi vlasnika gradskih zemljišta u Varaždinu iz druge polovice 17. stoljeća

na početku Dravičkog konca, ${ }^{33}$ most na nasipu kod Rogoznice ${ }^{34}$ i Kameni most na Plitvici.

U popisu iz 1695. godine unutrašnji grad je cjelina odvojena od suburbija. To je učinjeno novom teritorijalnom podjelom na tri četvrti: unutrašnji grad, gornji vanjski (sjeverni suburbij) i donji vanjski (južni suburbij). Popisani su vlasnici koji su živjeli u unutrašnjem gradu kao i svi fundusi koje su posjedovali unutar bedema i izvan njih. Nisu ga proveli četvrtari, već senator i kirurg Filip Krajačić i plemić Juraj Klik. Prepisao ga je i potpisao bilježnik Franjo Szembiborczy. Vlasnici zemljišta u unutrašnjem gradu plaćali su 6 rfl, ${ }^{35}$ a u suburbijima polovicu tog iznosa. Popisivači su utvrdili da 111 vlasnika posjeduje 206 fundusa u unutrašnjem gradu te 60 u suburbijima. Najveći posjednici su crkveni redovi, prelati, Generalat i tridesetnica. Isusovci posjeduju 15 fundusa u unutrašnjem gradu i 5,5 u suburbiju, sjemenište 10 u unutrašnjem gradu i pet u suburbiju, Generalat devet u unutrašnjem gradu i četiri vrta u suburbiju. Među plemstvom najveći posjednik je Petar Prašinski s 10 fundusa u unutrašnjem gradu i pet u suburbijima, slijede plemićke obitelji Draškovići, Druskoczy, Matija Marić, Patačići i vojnici Generalata. ${ }^{36}$

\section{POPIS IZ 1698. GODINE}

Sredstva prikupljena za popravak mostova 1695. nisu bila dovoljna pa se 1698. godine ponovno skupljaju. ${ }^{37}$ Popis svih vlasnika fundusa povezan je u jedinstvenu knjižicu. Najprije su popisani vlasnici unutrašnjeg grada, zatim južnog i sjevernog suburbija. Funduse su popisali općinski odbornik (vir communis) Grgur Zebec i brijač Matija Zgoinik. Popis je zaključen izvještajem o troškovima i predaji novca uz potpis bilježnika (Franje Kiša?).

Vlasnici su plaćali isti iznos kao i 1695. godine, 6 rfl za zemljišta u unutrašnjem gradu i 3 rfl za ona u suburbiju. Međutim, uz mnoge pripadnike svjetovnog i vojničkog plemstva, senatore, isusovce, Generalat i tridesetnicu upisano je nihil, što upućuje na probleme skupljanja novca ili oslobađanje dijela vlasnika od plaćanja. U unutrašnjem gradu popisano je 110 vlasnika koji su, uz 203 fundusa

33 ZPGV, VIII/1680., 337.

34 PGV, R. a., Računi kmetskog suca. Rogoznice je bila najsjeverniji dio gornjeg suburbija na putu prema Dravici, jednom od dravskih rukavaca na kojem su se nalazili mlinovi (op. a.).

35 Florenus Rhenensis (rajnska forinta).

36 PGV, R. a., Računi kmetskog suca.

37 Za posljednjih pet godina 17. stoljeća sačuvan je mali broj zapisnika pa nije moguće slijediti odluke magistrata povezane s radovima na obnovi gradskih mostova (op. a.). 
u unutrašnjem gradu, vlasnici 54 u suburbijima. Zapuštenih fundusa je 6,5 kao i tri od ukupno sedam vrtova. ${ }^{38}$ Neki su vlasnici broj funudsa smanjili, a drugi povećali. Protokoli s kraja 17. stoljeća svjedoče o dinamičnoj trgovini gradskim zemljištima te prodaji nekretnina novim stanovnicima grada. Jedan je od njih ban Adam Batthyany kojem je sin Petra Prašinskog, Petar Antun, prodao obiteljsku kuću na forumu. ${ }^{39}$

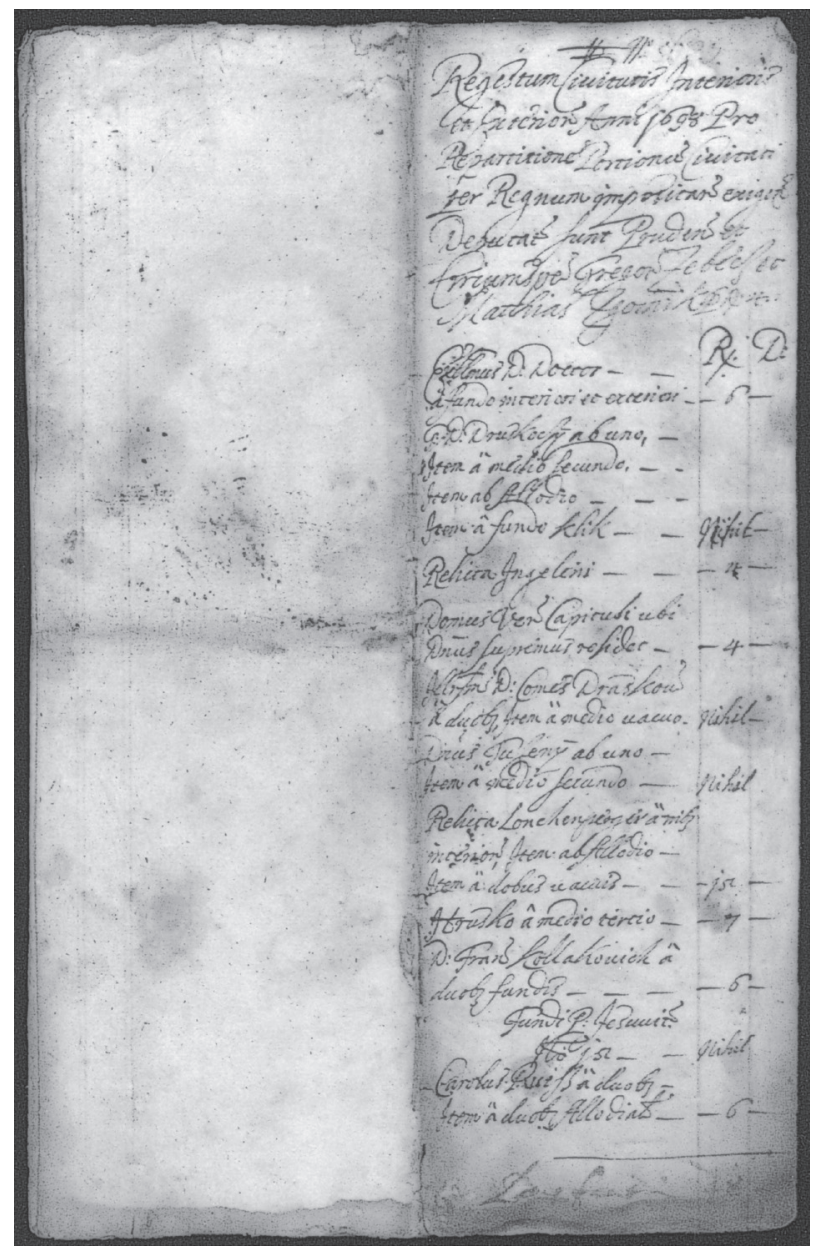

Slika 2. Popis iz 1698. godine, PGV, R. a., Računi kmetskog suca i tržnog nadzorništva 1632. - 1784.

38 PGV, R. a., Računi kmetskog suca.

39 ZPGV, IX/1695., 209. 
U suburbijima je popisano ukupno 245 vlasnika koji posjeduju 326 fundusa. Popisu treba pribrojiti 54 fundusa koje su u suburbijima posjedovali stanovnici unutrašnjeg grada, te je ukupan broj fundusa u suburbijima 380. Isusovci posjeduju ukupno 34 fundusa, franjevci i pavlini po tri kao i prelati. Generalat posjeduje 10 fundusa, a tridesetnica tri u unutrašnjem gradu. Broj fundusa koje posjeduju samostani, Crkva, kraljevske vojne i civilne službe ukupno je 46.

\section{STRUKTURA I VELIČINA GRADSKOG POSJEDA VLASNIKA FUNDUSA}

Popisima nisu obuhvaćene sve nekretnine koje su građani posjedovali, već samo one na području grada, zemljišta s kućama i gospodarskim zgradama, alodiji u suburbijima i vrtovi. ${ }^{40}$ Alodije u suburbijima posjeduju stanovnici unutrašnjeg grada. Od 111 vlasnika popisanih 1695. godine, 22 posjeduju alodije, od kojih neki, npr. trgovci Danijel Praunsperger i Karlo Ruesz, sudac Matija Marić, senator Matija Galjuf posjeduju po dva. Tri godine kasnije, 1698. godine, 110 vlasnika koji žive u unutrašnjem gradu posjeduje ukupno 257 fundusa na gradskom području.

Tablica 1. Prosječna veličina gradskog posjeda prema popisima iz druge polovice 17. stoljeća

\begin{tabular}{|l|c|c|c|}
\hline & 1669. & 1673. & 1698. \\
\hline u unutrašnjem gradu & & 1,52 & 1,84 \\
\hline u suburbijima & 1,09 & 1,09 & 1,40 \\
\hline ukupno & & $\mathbf{1 . 3}$ & $\mathbf{1 . 6 3}$ \\
\hline
\end{tabular}

Prosječna veličina gradskog posjeda u porastu je u unutrašnjem gradu dok u suburbijima raste tek na kraju 17. stoljeća. Ekonomska moć i društveni status još uvijek se izgrađivao posjedovanjem nekretnina i veličinom posjeda. Stanovnici unutrašnjeg grada posjeduju prosječno 1,5 - 2 fundusa, dok u suburbijima 1,1 - 1,4. S obzirom na to da popis iz 1698. godine uključuje i posjede koje vlasnici unutrašnjeg grada imaju u suburbijima, prosjek svih zemljišta koje posjeduju stanovnici unutrašnjeg grada još je viši i iznosi 2,33 fundusa. Građani suburbija posjeduju prosječno tek nešto više od jednog fundusa.

40 Na području gradske općine građani su posjedovali oranice, vinograde, sjenokoše, livade, šume, a na Dravici i Plitvici mlinove (op. a.). 

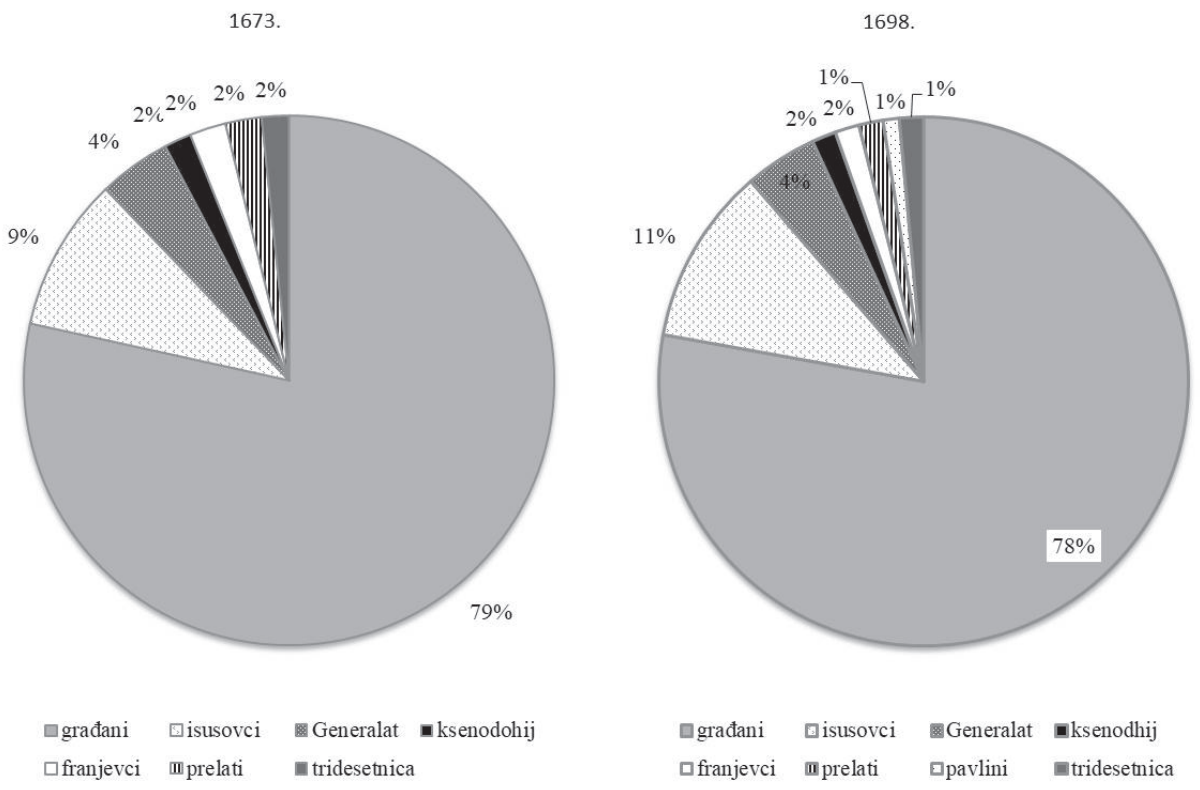

Grafikon 1 i 2. Udjel vlasništva građana, crkvenih redova, kraljevskih i vojnih službi u unutrašnjem gradu 1673. i 1698. godine

Na prosječnu veličinu posjeda dijelom su utjecali isusovci, prelati, Generalat i tridesetnica, čiji broj fundusa raste posebno u unutrašnjem gradu. Oni posjeduju više od 20 posto gradskog zemljišta. Najveći su pojedinačni vlasnici isusovci, ali treba uzeti u obzir to da fundusi na kojima se nalazi franjevački samostan i crkva nisu bili oporezovani i nemamo podatke o ukupnom broju njihovih fundusa. Struktura vlasništva građana unutrašnjeg grada pokazuje da se više od 75 posto njihovih nekretnina nalazilo u unutrašnjem gradu, a ostalo su alodiji i zemljišta u suburbijima. 


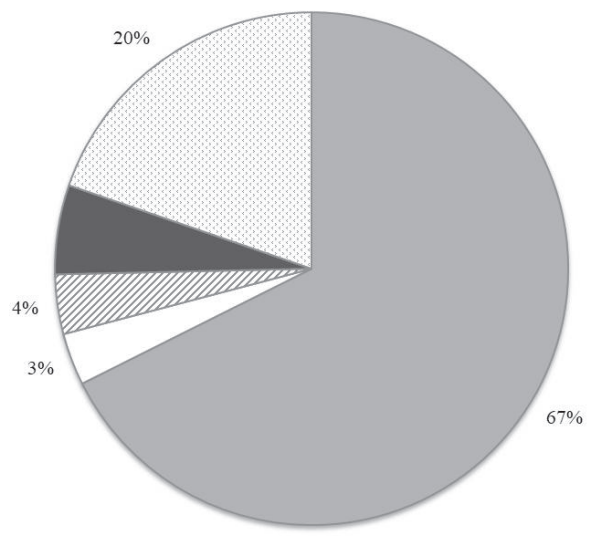

$\square$ fundusi, unutras̆ni grad $\square$ prazni fundusi $\circlearrowright$ vrtovi, unutras̆nj grad $\quad$ vanjski fundusi $\square$ alodiji

Grafikon 3. Struktura gradskog posjeda vlasnika u unutrašnjem gradu 1698. godine

Među vlasnicima ne nalazimo imena gradskih obitelji, dominantnih u ekonomskom i društvenom životu grada u prvoj polovici 17. stoljeća, već nove građane, vojnike i zapovjednike Slavonske krajine, visoko plemstvo i doseljenike, osobe koje se brzo uzdižu u društvenoj hijerarhiji i nadmeću u dobivanju gradskih službi. Posjed Ferdinanda Rueffa, zapovjednika tjelesne čete Generalata, obuhvaćao je 4,5 fundusau Habdelićevoj ulici. Poštar Ivan Gribec posjedovao je tri fundusa u Uršulinskoj ulici, senator i rizničar Grgur Zebec četiri fundusa između Gajeve i Kranjčevićeve ulice, a vojnik Žigmund Reizer, sin vojnika i licitara Baltazara Reizera, tri fundusa na parceli Gajeva - Bakačeva ulica.

\section{SOCIJALNA STRUKTURA VLASNIKA FUNDUSA}

Popisi potvrđuju promjene socijalne strukture gradskog stanovništva u drugoj polovici 17. stoljeća jednim dijelom povezane s promjenama koje se događaju unutar same zajednice, a drugim dijelom dolaskom novih stanovnika. U gradskoj zajednici, u kojoj su još početkom 17. stoljeća dominirali obrtnici i njihovi pomoćnici, kramari, ${ }^{41}$ Ackerbürger ${ }^{42}$ i težaci, sve su brojniji pripadnici gradske

41 Naziv za trgovce koji su robu prodavali po sajmovima (op. a.).

42 Prema Richardu van Dülmenu njem. Ackerbürger su stanovnici grada koji žive od poljoprivredne proizvodnje za razliku od Stadtbürger, koji se bave obrtom i trgovinom. Usp. Richard van DÜLMEN, 
elite s plemićkom titulom i brojnim nekretninama na području gradske općine. Promjenu socijalne strukture gradskog stanovništva potvrđuje pojedinačna veličina posjeda. U gradu, u kojem je još uvijek značajan dio stanovništva ovisio o proizvodnji hrane za vlastite potrebe i prodaju, svaka promjena veličine zemljišta utjecala je na njihov ekonomski i socijalni status.
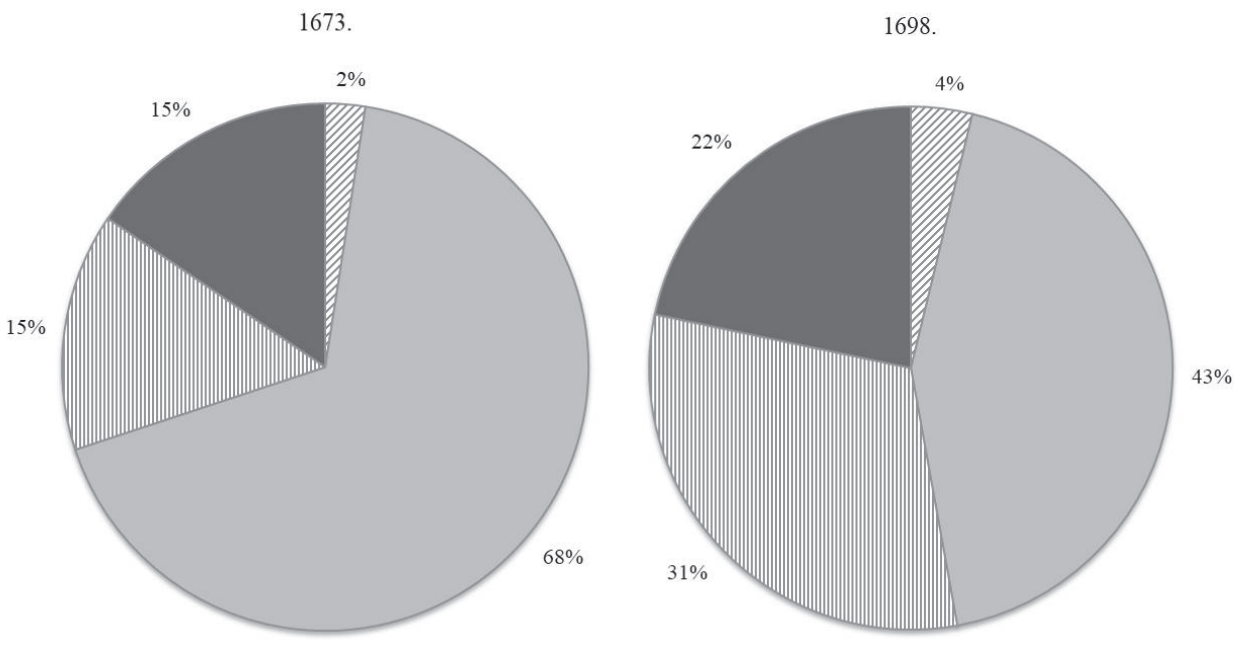

$\square 1 / 2$ fundusa $\square 1$ fundus $\mathbb{1}$ 1-2 fundusa $=$ više od 3 fundusa

$\square 1 / 2$ fundusa $\square 1$ fundus $\square$ 1-2 fundusa $\square$ više od 2 fundusa

Grafikon 4 i 5 . Usporedba veličine posjeda u unutrašnjem gradu 1673. i 1698. godine

Krajem 17. stoljeća sve je više imućnih građana, stranaca, plemstva, vojnika i zapovjednika, službenika Hrvatskog sabora i Varaždinske županije koji posjeduju više od jednog fundusa u unutrašnjem gradu. Omjer vlasnika jednog fundusa i onih s više od jednog 1673. godine bio je 70 : 30 posto, dok je na kraju stoljeća taj omjer 43 : 53 posto. Promjene upućuju na smanjenje broja kuća, a time i stanovnika u unutrašnjem gradu, što potvrđuju i popisi: 1673. godine popisano je 122 građana vlasnika fundusa, a 1698. godine 104.

Suburbiji pokazuju drugačiji trend. Umjesto objedinjavanja fundusa, koje pratimo u unutrašnjem gradu, fundusi se dijeli na sve manje čestice. To potvrđuju kupoprodajni ugovori u Protokolima u kojima vlasnici prodaju polovicu ili česticu zemljišta ili vrta.

Kultur und Alltag in der Frühen Neuzeit; Dorf und Stadt, Zweiter Band, C. H. Beck Verlag München, 1992., 62. 
1669.

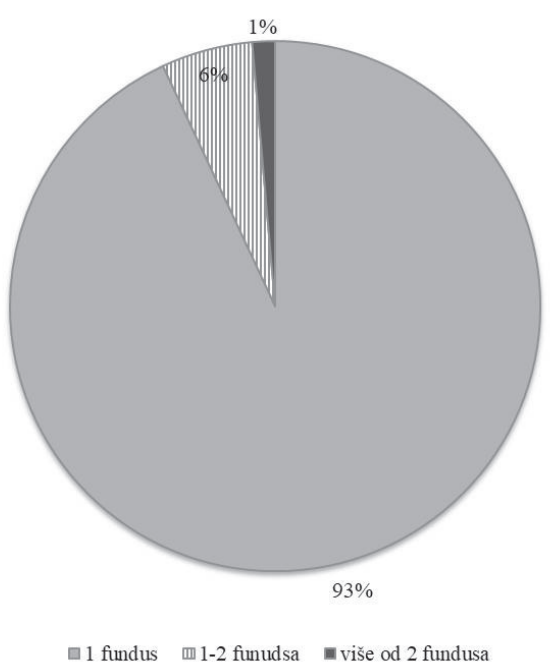

1698.

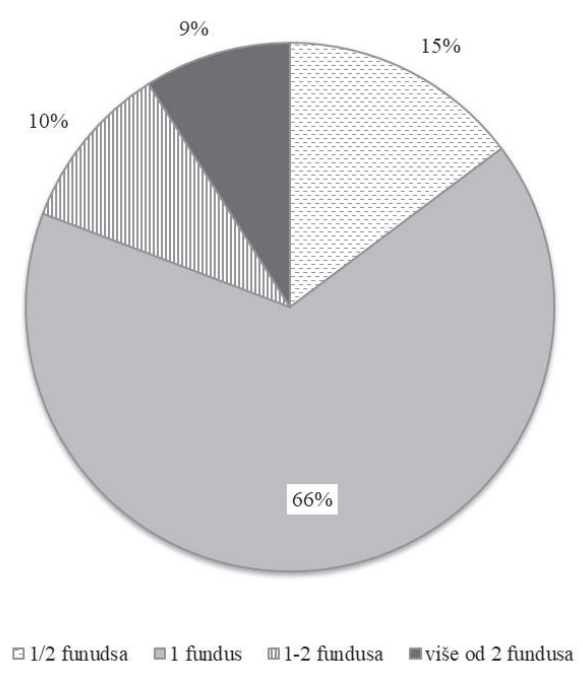

Grafikon 6 i 7. Usporedba veličine posjeda u sjevernom suburbiju 1673. i 1698. godine

Više od 90 posto vlasnika sjevernog suburbija 1669. godine posjeduje cijeli fundus, samo šest posto više od jednog, a vlasnici više od dva fundusa su rijetkost. Krajem stoljeća udjel vlasnika jednog fundusa se smanjuje, a raste broj vlasnika više fundusa. Dok popis iz 1669. godine nije zabilježio ni jednog vlasnika polovice fundusa, 1698. godine njih je 15 posto. To je pokazatelj veće gustoće stanovanja u suburbijima, ali i sve većeg broja siromašnih građana čija je ekonomska snaga u padu. Nasuprot tome, malobrojna gradska elita i dalje povećava svoje posjede kako u unutrašnjem gradu tako i u suburbijima. Dio tih posjeda nisu stekli kupovinom, već darivanjem općinskih nekretnina za navodne zasluge i gradske službe, što je u vrijeme sve većih socijalnih razlika izazvalo reakciju stanovništva. Tužba protiv magistrata 1698. godine upućena Hrvatskom saboru u ime siromašnih, udovica i siročadi pokazuje kakve je ekonomske i socijalne posljedice na gradsko društvo imao taj proces. ${ }^{43}$

43 Zaključci Hrvatskog sabora, sv. II, 1694. - 1713., Državni arhiv NR Hrvatske u Zagrebu, Zagreb, $1958 ., 166$. 


\section{PROCJENA BROJA STANOVNIKA}

Popisi vlasnika kuća u 16. stoljeću i broj vojnika koje je Varaždin morao uputiti u bansku vojsku u vrijeme Dugog turskog rata (1592. - 1606.) važan su sekundarni izvor u historiografiji za procjenu stanovnika grada Varaždina početkom ranog novog vijeka. U novije vrijeme relevantnim procjenama za razdoblje od kraja 16. do kraja 17. stoljeća smatraju se procjene Nevena Budaka i Hrvoja Petrića. Oni su analizom broja kuća u gradu, procjenom broja članova obitelji, stanovništva bez vlastitog posjeda, svećenika i broja vojnika došli do sličnih rezultata. Budak procjenjuje da je oko 1600 . godine Varaždin imao 2000 - 2300 stanovnika ${ }^{44}$, dok Petrić uzima u obzir i kmetove, kojih je bilo 800 - 900, pa procjenjuje da je cijelo varaždinsko gradsko područje imalo 2800 - 3200 stanovnika. ${ }^{45}$ Procjena Ante Gabričevića znatno se razlikuju od Budakovih i Petrićevih. Gabričević procjenjuje da je Varaždin krajem 16. stoljeća imao blizu 7000 stanovnika. ${ }^{46}$

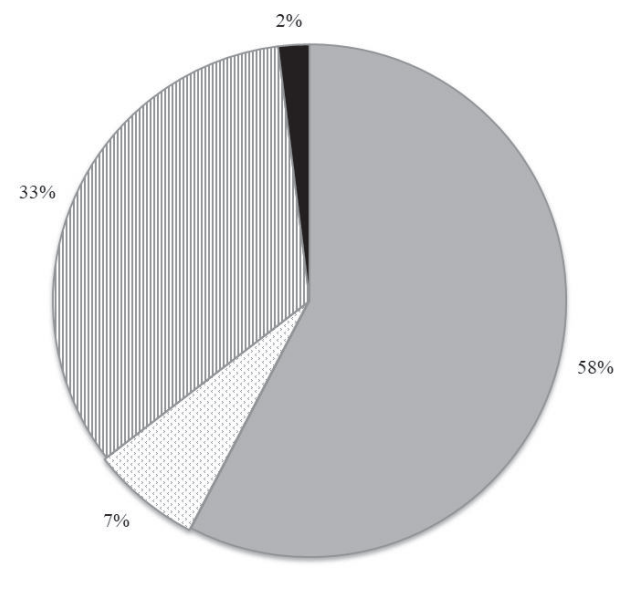

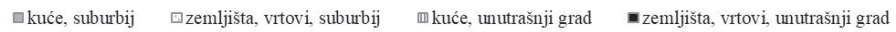

Grafikon 8. Trgovina gradskim zemljištima od 1684. do 1715. godine prema Protokolima

Za procjenu broja stanovnika krajem 17. stoljeća potrebno je utvrditi koliko je bilo naseljenih fundusa, odnosno kuća u gradu. Prema popisu iz 1698. godine

44 BUDAK, n. dj. 161.

45 Hrvoje PETRIĆ, Pogranična društva i okoliš; Varaždinski generalat i Križevačka županija u 17. stoljeću, Meridijani i Društvo za hrvatsku ekonomsku povijest i ekohistoriju, Samobor - Zagreb 2012., 278.

46 Ante GABRIČEVIĆ, Stanovništvo Varaždina tijekom minulih stoljeća, Hrvatska akademija znanosti i umjetnosti, Zavod za znanstveni rad Varaždin, Zagreb-Varaždin, 2002., 111. 
na području grada bilo je ukupno 583 fundusa, 203 u unutrašnjem gradu i 380 u suburbijima. Praznih zemljišta i vrtova u unutrašnjem gradu bilo je osam posto, u suburbijima tri posto. Takav odnos naseljenih i praznih fundusa potvrđuju kupoprodajni ugovori prema kojima se devet posto ugovora odnosi na trgovinu praznim zemljištima i vrtovima. Ukoliko oduzmemo funduse isusovaca, Crkve, Generalata i drugih službi, broj fundusa u unutrašnjem gradu bio je 165, u suburbijima 373, što je ukupno 538 na cijelom području grada. U obzir treba uzeti i to da su neke kuće i objekti, najviše u unutrašnjem gradu, izgrađeni na dva ili tri fundusa kao i to da je 15 posto vlasnika posjedovalo manje od fundusa. Međutim, veća kuća podrazumijevala je i veći broj ukućana kao što je manja podrazumijevala njih manje. Ako pretpostavimo da je zapuštenost nekih fundusa bila privremena, zbog požara, odlaska ili smrti vlasnika i sl. te je svaki fundus bio nastanjen obiteljima, stanarima, želirima i slugama, broj od 538 fundusa u vlasništvu građana polazište je za procjenu ukupnog broja stanovnika koji su živjeli u gradu.

Sljedeći je korak procjena broja članova obitelji i ostalih ukućana, naučnika i pomoćnika, slugu, inkvilina i stanara. Neven Budak procjenjuje da se na području grada početkom 17. stoljeća nalazilo 430 kuća. Kako procjenjuje da je na području grada živjelo 2000 - 2300 stanovnika, početkom 17. stoljeća broj je ukućana bio prosječno 4,77 do 5,3 po kući. ${ }^{47}$ Stjepan Krivošić donosi procjenu za grad Zagreb na temelju opisa Zagreba u spisu pavlina Ivana Benkovića iz 1668. godine te sačuvanih matičnih knjiga krštenih Župe sv. Marka iz druge polovice 17. stoljeća. Krivošić citira Benkovića koji navodi da je u zagrebačkoj varoši bilo 400 kuća u kojima je živjelo 2000 stanovnika, što znači da je u kućama živjelo prosječno petero ukućana, ali iz opisa ostaje nejasno odnosi li se broj kuća i stanovnika na Gradec, biskupski Kaptol ili oba naselja. Analizom matičnih knjiga rođenih (krštenih) Stjepan Krivošić dao je procjenu broja obitelji i stanovnika u Gradecu. Ako je u Gradecu i njegovom suburbiju živjelo 840 obitelji i 3600 stanovnika, prosječan broj članova obitelji bio je 4,3. ${ }^{48}$ Pomnožimo li najnižu procjenu broja članova obitelji u Gradecu Stjepana Krivošića i najvišu u Varaždinu Nevena Budaka s 538 varaždinskih fundusa, dolazimo do najmanje 2300, a najviše 2850 stanovnika. Tu nisu uključeni redovnici dvaju samostana, štićenici ksenodohija, svećenici, naučnici, pomoćnici, sluge i stanari u domaćinstvima kao ni vojnici ni službenici Generalata bez vlastitih nekretnina. Prema Protokolima u Varaždinu je u razdoblju od 1660. do 1684. godine živjelo najmanje 180 obrtnika i sedam trgovaca

47 BUDAK, n. dj. 161.

48 Stjepan KRIVOŠIĆ, Zagreb i njegovo stanovništvo od najstarijih vremena do sredine XIX. stoljeća, Jugoslavenska akademija znanosti i umjetnosti, Zagreb, 1981., 75-81. 
koji su imali najmanje jednog naučnika i pomoćnika. $U$ gradu je živjelo najmanje 33 svećenika i redovnika, a vojnika i službenika Generalata najmanje $90 .{ }^{49}$ Broju od 2300 do 2800 stanovnika treba pribrojiti još najmanje 500 osoba koje nisu bile vlasnici zemljišta ili su pripadale ukućanima te je grad Varaždin krajem 17. stoljeća mogao imati najmanje 2850 do 3350 stanovnika. Te se procjene odnose samo na grad, slobodni kraljevski grad bez stanovnika varaždinskog vlastelinstva i kmetova koji su živjeli u selima izvan gradskog područja.

\section{ZAKLJUČAK}

Porez na zemljište uobičajen je način ubiranja prihoda u korist državne ili lokalne vlasti. Takav način oporezivanja zahtijeva izradu katastra s popisom zemljišta i vlasnika te niz informacija o zemljištu važnih za razrezivanje poreza. $U$ gradu Varaždinu u 17. stoljeću osnova za razrezivanje poreza bio je fundus (grunt) od kojeg su se ubirali redovni i izvanredni porezi i gradske pristojbe. Najstarija poznata odluka magistrata o popisivanju vlasnika fundusa radi povećavanja poreza potječe iz 1599. godine.

Sačuvani popisi vlasnika fundusa iz druge polovice 17. stoljeća, od kojih je cjelovit samo popis iz 1698. godine, sadrže imena vlasnika fundusa na području grada te veličinu, vrstu, smještaj i kvalitetu zemljišta. Popisi razlikuju fundus, zapušten, prazan fundus, alodij i vrt. Popisivači popisuju vlasnike prema gradskim četvrtima u kojima su nastanjeni, prema unutrašnjem i vanjskom gradu, odnosno suburbiju. Analiza prosječne veličine posjeda potvrđuje da su tijekom druge polovice 17. stoljeća povećane ekonomske i socijalne razlike unutar gradskog društva. Stanovnici unutrašnjeg grada posjedovali su prosječno 1,5 - 2 fundusa, a u suburbijima 1,1 - 1,4. Tijekom stoljeća pratimo proces povećanja broja fundusa u vlasništvu senatora i drugih nositelja visokih službi u magistratu, plemstva, svećenstva te kraljevskih vojnih i civilnih službenika koji posjeduju više od 20 posto gradskog zemljišta. Procesom je posebno obuhvaćen unutrašnji grad u kojem se smanjuje gustoća stanovanja, dok se u suburbijima fundus dijeli na manje čestice i gustoća stanovanja se povećava. To su posljedice promjene društvene strukture stanovništva koja se s jedne strane događaju na ekonomskoj i socijalnoj razini, a s druge na javnoj, političkoj. Slabljenje ekonomske moći većine građana i gomilanje gradskih zemljišta u vlasništvu novostvorene gradske elite paralelna je s uspostavljanjem oligarhijskog obrasca vladanja.

49 Usp. BUREK, n. dj., 217. 
Popisi donose niz zanimljivih informacija o izgledu grada, o vlasnicima i nekretninama. Uz informacije o veličini i strukturi posjeda varaždinskih građana popisi sadrže informacije koje omogućuju procjenu broja stanovnika na kraju stoljeća. Na temelju broja nastanjenih fundusa i prosječnog broja ukućana procjenjuje se da je krajem 17. stoljeća u gradu živjelo između 2850 i 3350 stanovnika. Od deset sačuvanih popisa posebno je važan popis iz 1698. godine u kojem su popisani svi vlasnici i svi fundusi koje su posjedovali na području grada. Popis je važan izvor za istraživanje povijesti katastra grada Varaždina.

\section{IZVORI I BIBLIOGRAFIJA}

\section{Izvori}

1/ HR-DAVŽ-2. Poglavarstvo slobodnog i kraljevskog grada Varaždina, Radikalni arhiv

2/ HR-DAVŽ-2. Poglavarstvo grada Varaždina, Radikalni arhiv, Računi kmetskog suca i tržnog nadzorništva 1632. - 1784.

\section{Objavljeni izvori}

1/ Krešimir FILIĆ, Varaždinski mesarski ceh, Kulturno-prosvjetno vijeće općine Varaždin, Varaždin, 1968.

2/ Statuta civitatis Varasdiensis, preveli i priredili Josip KOLANOVIĆ i Mate KRIŽMAN, Državni arhiv u Varaždinu, Varaždin 2001.

3/ Zapisnici poglavarstva grada Varaždina, urednik: Josip BARBARIĆ, svesci I XI, Državni arhiv u Varaždinu, Varaždin, 1990. do 2006.

4/ Zaključci Hrvatskog sabora, sv. I i II, 1631. - 1713., Državni arhiv NR Hrvatske u Zagrebu, Zagreb, 1958.

\section{Knjige i članci}

1/ Neven BUDAK, Gradovi varaždinske županije u srednjem vijeku, Nakladna kuća dr. Feletar, Koprivnica, 1994.

2/ Višnja BUREK, Otkrivanje gradskih tajni; Varaždin u 17. stoljeću, HAZU Zavod za znanstveni rad u Varaždinu, Zagreb - Varaždin, 2019.

3/ Višnja BUREK, „Urbanistički razvoj varaždinskih suburbija tijekom 17. stoljeća“, Historia Varasdiensis, Vol. 1, No. 1, Društvo povjesničara grada Varaždina i Varaždinske županije, 2011. 
4/ Richard van DÜLMEN, Kultur und Alltag in der Frühen Neuzeit; Dorf und Stadt, Zweiter Band, C. H. Beck Verlag München, 1992.

5/ Ante GABRIČEVIĆ, Stanovništvo Varaždina tijekom minulih stoljeća, Hrvatska akademija znanosti i umjetnosti, Zavod za znanstveni rad Varaždin, Varaždin, 2002.

6/ Stjepan KRIVOŠIĆ, „Koprivnica - naselje i njegovi stanovnici: od sredine XVII. do sredine XIX. stoljeća“, Podravski zbornik, No.14, 1988.

7/ Stjepan KRIVOŠIĆ, „Stanovništvo Podravine 1659. - 1859. godine“, Podravski zbornik, No. 9., 1983.

8/ Stjepan KRIVOŠIĆ, Zagreb i njegovo stanovništvo od najstarijih vremena do sredine XIX. stoljeća, Jugoslavenska akademija znanosti i umjetnosti, Zagreb, 1981.

9/ Hrvoje PETRIĆ, Koprivnica u 17. stoljeću: okoliš, demografske, društvene $i$ gospodarske promjene u pograničnom gradu, Meridijani, Samobor, 2005.

10/ Hrvoje PETRIĆ, Pogranična društva i okoliš; Varaždinski generalat i Križevačka županija u 17. stoljeću, Meridijani i Društvo za hrvatsku ekonomsku povijest i ekohistoriju, Samobor - Zagreb, 2012.

\section{SUMMARY}

\section{PROPERTY OWNERSHIP RECORDS IN VARAŽDIN IN THE SECOND HALF OF THE 17TH CENTURY}

The city authorities in Varaždin compiled a number of lists of estate owners with the purpose of collecting the regular and supplementary taxes as well as other levies imposed by the city government. From the second half of the 17th century nine such records have been preserved, the last of which, dating from 1698 , is a complete document, while the rest refer only to certain city areas. The records also provide information on the number of parcels owned by Jesuits, Pauline Fathers, prelates, members of the Varaždin Generalate, and customs offices, which, as owners of city parcels, were also required to pay taxes. The amount of these taxes depended on the size of their parcels.

The analysis of the average size of estates shows that there is a noticeable economic and social divergence in the city during the second half of the 17th century. While the inner-city inhabitants owned 1.5-2 plots on average, in the suburbs the average estate size was between 1.1 and 1.4 plots. The average size 
of estates was affected by the owners of a larger number of plots, such as monasteries, the Church, and both military and civil services of the Kingdom. The number of their plots, particularly in the inner city is increasing and at the end of the 17th century they own more than twenty percent of city lands. The biggest individual owners are Jesuits. A larger number of plots is also owned by judges, senators and noblemen. In the suburbs, there is a completely different process at work. Instead of augmentation, the estates are being divided into smaller parcels of land. This proves a higher population density in the suburban areas, which resulted in an increased number of the poor and those citizens whose economic power is in decline.

Besides allowing the analysis of the economic and social processes in the city, the records are a valuable source in estimating the number of inhabitants in Varaždin at the end of the 17th century. Taking into consideration the number of uninhabited plots and the average number of household members, between 2,850 and 3,350 inhabitants are estimated to have lived in Varaždin at that time. Except for the names and plot sizes, the records also contain the information on locations, types, quality of these lands and the amount of taxes and duties paid. They are therefore an important source in investigating the history of the land register of the city of Varaždin.

Key Words: census; Varaždin; parcel; taxes; 17th century. 


\section{PRILOZI}

Tablica 2. Tablični prikaz broja fundusa i vlasnika u popisima od 1668. do 1698. godine

\begin{tabular}{|c|c|c|c|c|c|c|}
\hline godina & popisivač & područje & $\begin{array}{l}\text { ukupan } \\
\text { broj } \\
\text { fundusa }\end{array}$ & $\begin{array}{l}\text { prazni i } \\
\text { zapušteni } \\
\text { fundusi } \\
\end{array}$ & vrtovi & $\begin{array}{l}\text { broj } \\
\text { vlasnika } \\
\text { fundusa }\end{array}$ \\
\hline \multirow[t]{4}{*}{1668.} & Grgur Zajec & $\begin{array}{l}\text { sjeverni i sjeveroistočni } \\
\text { dio unutrašnjeg grada }\end{array}$ & 63 & 10 & 4 & 45 \\
\hline & Grgur Zajec & Ciglenica & 44 & - & 2 & 40 \\
\hline & & Brodovski konec & 111 & 4 & 2 & 108 \\
\hline & & ukupno: & 155 & & & 148 \\
\hline \multirow[t]{4}{*}{1669.} & Matija Kučić & $\begin{array}{l}\text { sjeverni i sjeveroistočni } \\
\text { dio unutrašnjeg grada }\end{array}$ & 61 & 10 & 2 & 46 \\
\hline & Matija Kučić & Ciglenica & 44 & - & 2 & 39 \\
\hline & & Brodovski konec & 112 & - & 1 & 104 \\
\hline & & ukupno: & 156 & & & 143 \\
\hline \multirow[t]{2}{*}{1670.} & $\begin{array}{l}\text { Juraj } \\
\text { Bedeković }\end{array}$ & $\begin{array}{l}\text { jugozapadni dio } \\
\text { unutrašnjeg grada }\end{array}$ & 45 & & 1 & 27 \\
\hline & $\begin{array}{l}\text { Juraj } \\
\text { Bedeković }\end{array}$ & $\begin{array}{l}\text { Dugi konec, Cargovec } \\
\text { i južni dio ophodne } \\
\text { ceste }\end{array}$ & 86 & 2 & & 74 \\
\hline \multirow[t]{2}{*}{1673.} & Stjepan Kučić & unutrašnji grad & 181 & & 4 & 127 \\
\hline & Juraj & sjeverni suburbij & 218 & & & 200 \\
\hline \multirow[t]{2}{*}{1695.} & $\begin{array}{l}\text { Filip Krajačić, } \\
\text { Juraj Klik }\end{array}$ & unutrašnji grad & 206 & & 7 & 111 \\
\hline & & $\begin{array}{l}\text { fundusi stanovnika } \\
\text { unutrašnjeg grada u } \\
\text { suburbijima }\end{array}$ & 87 & & & 35 \\
\hline \multirow[t]{5}{*}{1698.} & $\begin{array}{l}\text { Grgur Zebec, } \\
\text { Matija } \\
\text { Zgoinik }\end{array}$ & unutrašnji grad & 203 & $61 / 2$ & $7 \frac{1}{2}$ & 110 \\
\hline & & južni suburbij & 170 & 4 & 1 & 125 \\
\hline & & sjeverni suburbij & 156 & 1 & 2 & 129 \\
\hline & & $\begin{array}{l}\text { fundusi stanovnika } \\
\text { unutrašnjeg grada u } \\
\text { suburbijima }\end{array}$ & 54 & 4 & 1 & (31) \\
\hline & & ukupno & 583 & & & 367 \\
\hline
\end{tabular}


VIŠNJA BUREK: Popisi vlasnika gradskih zemljišta u Varaždinu iz druge polovice 17. stoljeća

Tablica 3. Vlasnici fundusa prema popisu iz 1698. godine

Unutrašnji grad

\begin{tabular}{|c|c|c|c|c|}
\hline unutrašnji grad & $\begin{array}{l}\text { vrsta } \\
\text { zemljišta }\end{array}$ & $\begin{array}{l}\text { broj } \\
\text { fundusa }\end{array}$ & $\begin{array}{l}\text { zanimanje, } \\
\text { služba vlasnika }\end{array}$ & moguće lokacije \\
\hline \multirow[t]{2}{*}{$\begin{array}{l}\text { Excellentissimus D: Doctor } \\
\text { (Korlek Godefriedus) }\end{array}$} & fundus & 1 & doktor & $\begin{array}{l}\text { Kukuljevićeva } \\
\text { ulica? }\end{array}$ \\
\hline & $\begin{array}{l}\text { fundus, } \\
\text { vanjski }\end{array}$ & 1 & & \\
\hline \multirow[t]{3}{*}{ D: Druskoczy } & fundus & $1 \frac{1}{2}$ & & $\begin{array}{l}\text { Kukuljevićeva } \\
\text { ulica? }\end{array}$ \\
\hline & alodij & 1 & & \\
\hline & $\begin{array}{l}\text { fundus } \\
\text { Klik }\end{array}$ & 1 & & \\
\hline $\begin{array}{l}\text { ud. Ingelini (Fucellini Henrika } \\
\text { Fridrika de Enne, Magdalena } \\
\text { Riđanec) }\end{array}$ & fundus & 1 & $\begin{array}{l}\text { ud. vojnog } \\
\text { kirurga }\end{array}$ & $\begin{array}{l}\text { forum civitatis } \\
\text { (Trg kralja } \\
\text { Tomislava) }^{51} \\
\end{array}$ \\
\hline kuća Zagrebačkog biskupa & fundus & 1 & prelat & forum civitatis \\
\hline \multirow[t]{2}{*}{ D: comes Drašković } & fundus & 2 & & forum civitatis \\
\hline & $\begin{array}{l}\text { fundus, } \\
\text { prazni }\end{array}$ & $1 / 2$ & & forum civitatis \\
\hline $\begin{array}{l}\text { Tuszeny (Franjo Vilim Teseny, } \\
\text { pl.) }\end{array}$ & fundus & $1 \frac{1}{2}$ & $\begin{array}{l}\text { zapovjednik } \\
\text { straže } \\
\text { varaždinske } \\
\text { regimente } \\
\end{array}$ & $\begin{array}{l}\text { u ulici kod } \\
\text { isusovačke crkve }\end{array}$ \\
\hline \multirow[t]{3}{*}{$\begin{array}{l}\text { ud. Lochenperger } \\
\text { (Ferdinanda, Goser Marija) }\end{array}$} & fundus & 2 & $\begin{array}{l}\text { ud. vojnika, } \\
\text { zapovjednika } \\
\text { straže }\end{array}$ & $\begin{array}{l}\text { uz istočni } \\
\text { bedem }\end{array}$ \\
\hline & alodij & 1 & & $\begin{array}{l}\text { Brodovski konec } \\
\text { (Trenkova ulica) }\end{array}$ \\
\hline & $\begin{array}{l}\text { fundus, } \\
\text { prazni }\end{array}$ & 2 & & \\
\hline Hruško (Andrija) & fundus & $1 / 2$ & plaćenik & $\begin{array}{l}\text { Mala ulica } \\
\text { (Kranjčevićeva } \\
\text { ulica) } \\
\end{array}$ \\
\hline Franjo Kolaković, pl. & fundus & 2 & & $\begin{array}{l}\text { uz istočni } \\
\text { bedem }\end{array}$ \\
\hline
\end{tabular}

50 Zanimanja i moguće lokacije fundusa određene su usporedbom s kupoprodajnim ugovorima i drugim informacijama iz Protokola (op. a.).

51 Nazivi ulica u zagradi su suvremeni nazivi ulica. 
Radovi Zavoda za znanstveni rad HAZU Varaždin; br. 31, 2020, str. 31-74

\begin{tabular}{|c|c|c|c|c|}
\hline isusovci & & 15 & & \begin{tabular}{|l} 
Pavlinska - \\
Habdelićeva \\
ulica
\end{tabular} \\
\hline \multirow[t]{2}{*}{ Karlo Ruesz, pl. } & fundus & 2 & $\begin{array}{l}\text { trgovac, sudac, } \\
\text { senator }\end{array}$ & forum civitatis \\
\hline & alodij & 2 & & \\
\hline $\begin{array}{l}\text { Domus Gualandro } \\
\text { (Guallander) }\end{array}$ & fundus & $1 \frac{1}{4}$ & trgovci, Ptuj & forum civitatis \\
\hline $\begin{array}{l}\text { ud. Sušić (Jakoba, Katarina } \\
\text { Božaković) }\end{array}$ & fundus & $1 \frac{1}{4}$ & ud. gumbara & $\begin{array}{l}\text { Velika ulica } \\
\text { (Gajeva ulica) }\end{array}$ \\
\hline \multirow[t]{2}{*}{ Martin Leher (Lehar), Glasar, } & fundus & $2 \frac{1}{2}$ & staklar & $\begin{array}{l}\text { Ulica sv. Nikole } \\
\text { (Draškovićeva } \\
\text { ulica) }\end{array}$ \\
\hline & alodij & 1 & & $\begin{array}{l}\text { Milički konec } \\
\text { (Vrazova ulica) }\end{array}$ \\
\hline D: Gusić (Nikola, pok.) & fundus & 1 & $\begin{array}{l}\text { zapovjednik u } \\
\text { Sredičkom }\end{array}$ & $\begin{array}{l}\text { Seminariumska } \\
\text { ulica } \\
\text { (Habdelićeva } \\
\text { ulica) }\end{array}$ \\
\hline nasljednici Riđanec & fundus & 2 & & $\begin{array}{l}\text { Seminariumska } \\
\text { ulica }\end{array}$ \\
\hline \multirow[t]{2}{*}{ Franjo Novoselić } & fundus & 1 & & Ulica sv. Nikole \\
\hline & fundus & 1 & & \\
\hline $\begin{array}{l}\text { ud. Glasar (Šimuna, } \\
\text { Margareta) }\end{array}$ & $\begin{array}{l}\text { fundus } \\
\text { sub fosatu }\end{array}$ & 1 & ud. staklara & $\begin{array}{l}\text { Seminariumska } \\
\text { ulica }\end{array}$ \\
\hline D: Franjo Vagić & fundus & 2 & $\begin{array}{l}\text { potkapetan u } \\
\text { Križevcima }\end{array}$ & $\begin{array}{l}\text { Seminariumska } \\
\text { ulica }\end{array}$ \\
\hline \multirow[t]{2}{*}{ Fundus seminarii } & fundus & $71 / 2$ & & $\begin{array}{l}\text { Seminariumska } \\
\text { ulica }\end{array}$ \\
\hline & alodij & 1 & & Brodovski konec \\
\hline $\begin{array}{l}\text { D: Rittmeister (Ferdinand } \\
\text { Rueff) }\end{array}$ & fundus & $41 / 2$ & $\begin{array}{l}\text { zapovjednik } \\
\text { tjelesne čete }\end{array}$ & $\begin{array}{l}\text { Seminariumska } \\
\text { ulica }\end{array}$ \\
\hline $\begin{array}{l}\text { Tobija Dogmess (Pachmes, } \\
\text { pl.) }\end{array}$ & fundus & 1 & & $\begin{array}{l}\text { Seminariumska } \\
\text { ulica }\end{array}$ \\
\hline Juraj Nadiser, Pek & fundus & 1 & pekar & Ulica sv. Nikole \\
\hline Mihael Smolčić & fundus & 1 & & $\begin{array}{l}\text { kod Donjih vrata } \\
\text { (Trg slobode) }\end{array}$ \\
\hline
\end{tabular}


VIŠNJA BUREK: Popisi vlasnika gradskih zemljišta u Varaždinu iz druge polovice 17. stoljeća

\begin{tabular}{|c|c|c|c|c|}
\hline Franjo Šišković & fundus & 1 & $\begin{array}{l}\text { senator, } \\
\text { podsudac } \\
\text { Varaždinske } \\
\text { županije }\end{array}$ & kod Donjih vrata \\
\hline & alodij & 2 & & \\
\hline Domus Szereny (Žigmund, pl.) & fundus & 1 & & kod Donjih vrata \\
\hline \multirow[t]{2}{*}{$\begin{array}{l}\text { kuća lepoglavskih pavlina } \\
\text { (kuća Šeligović) }\end{array}$} & fundus & 1 & & $\begin{array}{l}\text { uličica mesara } \\
\text { (Školska ulica) }\end{array}$ \\
\hline & alodij & 2 & & $\begin{array}{l}\text { Dugi konec } \\
\text { (Zagrebačka } \\
\text { ulica) }\end{array}$ \\
\hline \multirow[t]{2}{*}{ Ivan Kuhar(ec) gumbar } & fundus & 1 & gumbar & \\
\hline & $\begin{array}{l}\text { fundus, } \\
\text { prazni, } \\
\text { vanjski }\end{array}$ & 1 & & \\
\hline Franjo Walth ( Wolth, Wolle) & fundus & 1 & apotekar & $\begin{array}{l}\text { Gundulićeva } \\
\text { ulica }\end{array}$ \\
\hline Petar Horvat & fundus & 1 & & \\
\hline D: Prothonotar (Juraj Plemić) & fundus & 2 & protonotar & \\
\hline Kuća gospodina generala & fundus & 4 & & Franjevački trg \\
\hline Martin Muer & fundus & 1 & $\begin{array}{l}\text { trgovac, } \\
\text { kramar }\end{array}$ & Franjevački trg \\
\hline Urban zidar & fundus & 1 & zidar & \\
\hline $\begin{array}{l}\text { Ivan Taugensperk } \\
\text { (Taugenperg) }\end{array}$ & fundus & 1 & $\begin{array}{l}\text { konjanik } \\
\text { tjelesne čete } \\
\text { Varaždinskog } \\
\text { generalata }\end{array}$ & $\begin{array}{l}\text { Fraterska ulica } \\
\text { (Kranjčevićeva } \\
\text { ulica) }\end{array}$ \\
\hline Petar Pankarić & fundus & 1 & & \\
\hline \multirow[t]{2}{*}{ Matija Galjuf, pl. } & fundus & 2 & sudac & Ulica sv. Nikole \\
\hline & $\begin{array}{l}\text { fundus, } \\
\text { alodijalni }\end{array}$ & $21 / 2$ & & $\begin{array}{l}\text { Cargovec } \\
\text { (Supilova ulica) }\end{array}$ \\
\hline Nikola Škarica, pl. & fundus & 1 & senator, sudac & Ulica sv. Nikole \\
\hline \multirow[t]{2}{*}{ Grgur Ramprecht } & fundus & 1 & tamničar & uličica mesara \\
\hline & $\begin{array}{l}\text { fundus, } \\
\text { prazni }\end{array}$ & 1 & & \\
\hline zemljište mesara & fundus & 1 & & uličica mesara \\
\hline $\begin{array}{l}\text { Domus profoziana (zatvor } \\
\text { Generalata) }\end{array}$ & fundus & 1 & & uličica mesara \\
\hline Nikola Horvatić & fundus & 1 & & \\
\hline
\end{tabular}


Radovi Zavoda za znanstveni rad HAZU Varaždin; br. 31, 2020, str. 31-74

\begin{tabular}{|c|c|c|c|c|}
\hline Mihael Szopfsky & fundus & 1 & & \\
\hline \multirow[t]{2}{*}{ Juraj Kallander } & fundus & $1 \frac{1}{2}$ & senator, sudac & Ulica sv. Nikole \\
\hline & alodij & 1 & & $\begin{array}{l}\text { Vidovski konec } \\
\text { (Blažekova ulica) }\end{array}$ \\
\hline \multirow[t]{2}{*}{ Domus Antolčić (Ivana, pl.) } & fundus & $1 \frac{1}{2}$ & tridesetničar & Mala ulica \\
\hline & alodij & 4 & & $\begin{array}{l}\text { Dravički konec } \\
\text { (Starčevićeva } \\
\text { ulica) }\end{array}$ \\
\hline \multirow[t]{2}{*}{ Ivan Trok (Tročak) } & fundus & 3 & vojnik, pivar & Ulica sv. Nikole \\
\hline & alodij & 2 & & \\
\hline \multirow[t]{4}{*}{ D: Matija Marić } & fundus & 1 & senator, sudac & Ulica sv. Nikole \\
\hline & vrt & $1 / 2$ & & \\
\hline & $\begin{array}{l}\text { kuća } \\
\text { Modrinjak }\end{array}$ & 1 & & \\
\hline & $\begin{array}{l}\text { fundus, } \\
\text { alodijalni }\end{array}$ & 2 & & \\
\hline \multirow[t]{5}{*}{$\begin{array}{l}\text { ud. Petrović (Matije, pl., } \\
\text { Elizabeta Vizer (Bizerin) }\end{array}$} & fundus & 1 & $\begin{array}{l}\text { ud. gradskog } \\
\text { i plemićkog } \\
\text { suca }\end{array}$ & Ulica sv. Nikole \\
\hline & $\begin{array}{l}\text { vrt, } \\
\text { zapušten }\end{array}$ & 1 & & \\
\hline & alodij & 1 & & uz Dravicu \\
\hline & fundus & 2 & & uz Dravicu \\
\hline & alodij & 3 & & Slopanec \\
\hline Grenkoff Tisliar & funuds & 1 & stolar & \\
\hline \multirow[t]{2}{*}{ D: Prothonotar (Juraj Plemić) } & fundus & 4 & protonotar & $\begin{array}{l}\text { ugao } \\
\text { Draškovićeve i } \\
\text { Kačićeve ulice }\end{array}$ \\
\hline & \begin{tabular}{|l} 
fundus, \\
vanjski
\end{tabular} & 1 & & \\
\hline \multirow[t]{2}{*}{ Bartol Zimić } & fundus & 1 & bačvar, rizničar & $\begin{array}{l}\text { Kačićeva - } \\
\text { Uršulinska ulica }\end{array}$ \\
\hline & $\begin{array}{l}\text { fundus, } \\
\text { alodijalni }\end{array}$ & 1 & & $\begin{array}{l}\text { uz obrambeni } \\
\text { jarak (Vrazova } \\
\text { ulica) }\end{array}$ \\
\hline \multirow[t]{2}{*}{ kuća tridesetnice } & $\begin{array}{l}\text { fudus sa } \\
\text { stajama }\end{array}$ & 2 & & Uršulinska ulica \\
\hline & fundus & 1 & & \\
\hline kuća Zagrebačkog kaptola & fundus & 2 & prelati & Uršulinska ulica \\
\hline
\end{tabular}


VIŠNJA BUREK: Popisi vlasnika gradskih zemljišta u Varaždinu iz druge polovice 17. stoljeća

\begin{tabular}{|c|c|c|c|c|}
\hline Ivan Koller Trombetaš & fundus & 2 & \begin{tabular}{|l} 
trubač \\
tjelesne čete \\
Varaždinskog \\
generalata \\
\end{tabular} & Uršulinska ulica \\
\hline Postmaister Gribecz (Ivan) & fundus & 3 & $\begin{array}{l}\text { poštar, } \\
\text { zastavnik } \\
\text { varaždinske } \\
\text { čete }\end{array}$ & Uršulinska ulica \\
\hline \multirow[t]{2}{*}{ Vito Paur Czimerman } & fundus & 1 & tesar & Uršulinska ulica \\
\hline & $\begin{array}{l}\text { vrt, } \\
\text { zapušten }\end{array}$ & 1 & & \\
\hline \multirow[t]{2}{*}{ Domus Expeditonis } & fundus & 2 & & \\
\hline & vrt & 1 & & \\
\hline Franjo Bučić pintar & fundus & 2 & bačvar & Ulica sv. Nikole \\
\hline Nikola Keszlin pintar & fundus & $1 \frac{1}{2}$ & bačvar & \\
\hline Staje Generalata & fundus & 4 & & Padovčeva ulica \\
\hline Juraj Czindery & fundus & $1 / 2$ & $\begin{array}{l}\text { prokurator, } \\
\text { bilježnik, } \\
\text { podžupan } \\
\text { Varaždinske } \\
\text { županije }\end{array}$ & Padovčeva ulica \\
\hline \multirow[t]{2}{*}{ Ivan Boniccelli } & fundus & 2 & trgovac & Franjevački trg \\
\hline & $\begin{array}{l}\text { fundus, } \\
\text { vanjski }\end{array}$ & 1 & & \\
\hline \multirow[t]{2}{*}{ Vito Omasz } & fundus & 1 & & Fraterska ulica \\
\hline & $\begin{array}{l}\text { vrt, } \\
\text { vanjski }\end{array}$ & 1 & & \begin{tabular}{|l|} 
Ciglenica \\
(Trstenjakova \\
ulica)
\end{tabular} \\
\hline \multirow[t]{2}{*}{$\begin{array}{l}\text { Domus Ottmichiana (Otmić } \\
\text { Juraj, pl.) }\end{array}$} & fundus & 2 & & $\begin{array}{l}\text { Gundulićeva } \\
\text { ulica }\end{array}$ \\
\hline & $\begin{array}{l}\text { fundus, } \\
\text { prazni }\end{array}$ & 1 & & \\
\hline \multirow[t]{2}{*}{ Jakob Glik (Klik) } & fundus & $1 \frac{1}{2}$ & plaćenik & \\
\hline & alodij & 1 & & \\
\hline \multirow[t]{2}{*}{ Juraj Pertmizer, postar } & fundus & 1 & poštar & \\
\hline & vrt & $1 / 4$ & & \\
\hline $\begin{array}{l}\text { Pincerna Arcensis (krčma } \\
\text { Erdődyja) }\end{array}$ & fundus & 1 & & Fraterska ulica \\
\hline
\end{tabular}




\begin{tabular}{|c|c|c|c|c|}
\hline D: Szalakovich & fundus & 1 & $\begin{array}{l}\text { konjanik } \\
\text { tjelesne čete } \\
\text { Varaždinskog } \\
\text { generalata }\end{array}$ & \\
\hline Franjo (Antun) Hortman, pl. & fundus & $1 / 2$ & & Fraterska ulica \\
\hline $\begin{array}{l}\text { ud. Majcen (Franje starijeg, } \\
\text { Elizabeta Šimunić, pl.) }\end{array}$ & fundus & $1 / 2$ & $\begin{array}{l}\text { ud. podžupana } \\
\text { Križevačke } \\
\text { županije i } \\
\text { protonotara }\end{array}$ & Fraterska ulica \\
\hline Sopunar (Henczlin Godfried) & fundus & 1 & sapunar & Fraterska ulica \\
\hline Pavao Kobfer, klanfar & fundus & 1 & klanfar (limar) & \\
\hline \multirow[t]{2}{*}{ Martin Muer, pl. } & fundus & 2 & trgovac & Franjevački trg \\
\hline & \begin{tabular}{|l|} 
fundus, \\
vanjski \\
\end{tabular} & 2 & & $\begin{array}{l}\text { uz obrambeni } \\
\text { jarak }\end{array}$ \\
\hline \multirow[t]{3}{*}{$\begin{array}{l}\text { ud. Martina Prosenjaka (Ana } \\
\text { Marija Bristoff, pl.) }\end{array}$} & fundus & 1 & & Franjevački trg \\
\hline & alodij & $1 / 2$ & & Dravički konec \\
\hline & vrt & 1 & & \\
\hline \multirow[t]{2}{*}{ Juraj Mikulčić } & fundus & 1 & $\begin{array}{l}\text { senator, } \\
\text { podsudac } \\
\text { Varaždinske } \\
\text { županije }\end{array}$ & forum civitatis \\
\hline & alodij & 1 & & Slopanec \\
\hline $\begin{array}{l}\text { Excellentissimus D: comes } \\
\text { Banus (Adam Batthiany) }\end{array}$ & fundus & 3 & ban & forum civitatis \\
\hline gospodin biskup & fundus & 1 & prelat & forum civitatis \\
\hline \multirow[t]{5}{*}{ Grgur Zebec } & fundus & 2 & $\begin{array}{l}\text { rizničar, } \\
\text { senator }\end{array}$ & Velika ulica \\
\hline & $\begin{array}{l}\text { fundus, } \\
\text { prazni }\end{array}$ & 1 & & \\
\hline & vrt & $1 / 4$ & & \\
\hline & $\begin{array}{l}\text { fundus, } \\
\text { zapušten, } \\
\text { vanjski } \\
\end{array}$ & 2 & & \\
\hline & alodij & 1 & & Brodovski konec \\
\hline fundus Dux.. & fundus & 1 & & \\
\hline Martin Czibin & fundus & 1 & vagmeštar & Velika ulica \\
\hline $\begin{array}{l}\text { Mihael Hueber (Huebner), } \\
\text { snaiczar }\end{array}$ & fundus & 1 & snaiczar & Velika ulica \\
\hline
\end{tabular}


VIŠNJA BUREK: Popisi vlasnika gradskih zemljišta u Varaždinu iz druge polovice 17. stoljeća

\begin{tabular}{|c|c|c|c|c|}
\hline & $\begin{array}{l}\text { fundus, } \\
\text { prazni, } \\
\text { vanjski }\end{array}$ & 1 & & \\
\hline ud. Martinčević & fundus & 1 & & \\
\hline Juraj Bittok & $\begin{array}{l}\text { fundus, } \\
\text { prazni }\end{array}$ & 2 & & \\
\hline Juraj (Grgur) Lorber & fundus & 1 & $\begin{array}{l}\text { sudac } \\
\text { varaždinske } \\
\text { regimente }\end{array}$ & Velika ulica \\
\hline $\begin{array}{l}\text { ud. Gaszony (Gazon Ivan } \\
\text { Baberista) }\end{array}$ & fundus & 1 & $\begin{array}{l}\text { ud. vojnika } \\
\text { tjelesne čete } \\
\text { Varaždinskog } \\
\text { generalata }\end{array}$ & \\
\hline Doroteja Futak & fundus & 1 & & Velika ulica \\
\hline \multirow[t]{2}{*}{ Baltazar Pek } & fundus & 1 & pekar & Velika ulica \\
\hline & fundus & 1 & & \\
\hline \multirow[t]{2}{*}{ Ivan Lukavszky } & fundus & 1 & & \\
\hline & alodij & 1 & & \\
\hline Pavao Horvatić & fundus & 1 & & \\
\hline \multirow[t]{3}{*}{ Magnus D: Petar Prašinski, pl. } & fundus & 3 & $\begin{array}{l}\text { tridesetničar, } \\
\text { podžupan } \\
\text { Varaždinske } \\
\text { županije }\end{array}$ & $\begin{array}{l}\text { u području tvrđe } \\
\text { (Stančićev trg) }\end{array}$ \\
\hline & $\begin{array}{l}\text { zapušten } \\
\text { vrt }\end{array}$ & 1 & & Padovčeva ulica \\
\hline & $\begin{array}{l}\text { fundus, } \\
\text { alodijalni }\end{array}$ & 2 & & Ciglenica \\
\hline Martin Rokaj & fundus & 1 & & \\
\hline Juraj vratar & fundus & 1 & vratar & \\
\hline Grgur Butte & fundus & 1 & & \\
\hline $\begin{array}{l}\text { D: Franjo Wisscher (Viser), } \\
\text { stobholitar }\end{array}$ & fundus & 1 & stobholitar & Velika ulica \\
\hline \multirow[t]{2}{*}{ Fabijan Kučić } & fundus & 2 & vir communis & Velika ulica \\
\hline & $\begin{array}{l}\text { fundus, } \\
\text { alodijalni }\end{array}$ & 1 & & \\
\hline Tomo Dorner & fundus & 2 & pekar & Velika ulica \\
\hline \multirow[t]{2}{*}{ Mihael Fabijančić } & fundus & $1 \frac{1 / 4}{}$ & čizmar & Velika ulica \\
\hline & alodij & 1 & & Dravički konec \\
\hline Petar Bartolić & fundus & $1 \frac{1}{4}$ & $\begin{array}{l}\text { vir communis, } \\
\text { tržni nadzornik }\end{array}$ & Velika ulica \\
\hline
\end{tabular}


Radovi Zavoda za znanstveni rad HAZU Varaždin; br. 31, 2020, str. 31-74

\begin{tabular}{|c|c|c|c|c|}
\hline & alodij & 2 & & \\
\hline Matija Zgoinik & fundus & 1 & brijač & Velika ulica \\
\hline \multirow[t]{2}{*}{ Nikola Košćak } & fundus & 1 & četvrtar & Velika ulica \\
\hline & $\begin{array}{l}\text { fundus, } \\
\text { alodijalni }\end{array}$ & 2 & & \\
\hline Mihael Domitrović & fundus & $1 \frac{1}{2}$ & & Velika ulica \\
\hline Andrija Horvatić & fundus & $1 \frac{1}{2}$ & & Velika ulica \\
\hline \multirow[t]{2}{*}{ Franjo Vispoher, kotlar } & fundus & 1 & kotlar & Velika ulica \\
\hline & fundus, & $1 / 2$ & & \\
\hline Matija Keffer & fundus & 1 & vir communis & Velika ulica \\
\hline \multirow[t]{2}{*}{ Ivan Sović } & fundus & 1 & $\begin{array}{l}\text { vojnik, } \\
\text { skulptor }\end{array}$ & Velika ulica \\
\hline & $\begin{array}{l}\text { fundus, } \\
\text { alodijalni }\end{array}$ & 1 & & \\
\hline \multirow[t]{2}{*}{ Andrija Probazer } & fundus & 3 & & $\begin{array}{l}\text { Bakačeva ulica, } \\
\text { istočni dio? }\end{array}$ \\
\hline & vrt & $3 / 4$ & & \\
\hline Špoljar(ić Martin) sub fosato & fundus & 1 & & $\begin{array}{l}\text { uz obrambeni } \\
\text { jarak }\end{array}$ \\
\hline fundus Vrban & fundus & 1 & & \\
\hline \multirow[t]{2}{*}{ Žigmund Reizler (Reiser) } & fundus & 3 & licitar? & $\begin{array}{l}\text { Bakačeva ulica, } \\
\text { zapadni dio? }\end{array}$ \\
\hline & $\begin{array}{l}\text { fundus, } \\
\text { alodijalni }\end{array}$ & 2 & & \\
\hline Domus Patachichiana & fundus & $31 / 2$ & & \\
\hline
\end{tabular}

Južni suburbij

\begin{tabular}{|l|l|l|l|l|}
\hline južni suburbij & $\begin{array}{l}\text { vrsta } \\
\text { zemljišta }\end{array}$ & $\begin{array}{l}\text { broj } \\
\text { fundusa }\end{array}$ & $\begin{array}{l}\text { zanimanje, } \\
\text { služba } \\
\text { vlasnika }\end{array}$ & moguće lokacije \\
\hline Domus Hansliana & fundus & 2 & & \\
\hline D: Dervodelić Ivan, & fundus & $1 \frac{1 / 2}{2}$ & $\begin{array}{l}\text { uz obrambeni } \\
\text { jarak }\end{array}$ \\
\hline Franjo Szembiborczy, pl. & fundus & 2 & $\begin{array}{l}\text { senator, } \\
\text { bilježnik }\end{array}$ & $\begin{array}{l}\text { Szpasnik u } \\
\text { ulici Cargovec } \\
\text { (Supilova ulica) }\end{array}$ \\
\hline & fundus, \\
\end{tabular}


VIŠNJA BUREK: Popisi vlasnika gradskih zemljišta u Varaždinu iz druge polovice 17. stoljeća

\begin{tabular}{|c|c|c|c|c|}
\hline & mlin & $1 / 2$ & & na Dravici \\
\hline Petar Tretinjak, & fundus & $1 / 2$ & & Cargovec \\
\hline Pauko, prije D: Makara & fundus & 1 & & Cargovec \\
\hline \multirow[t]{2}{*}{$\begin{array}{l}\text { D: Magnus Makar (Ivan } \\
\text { Andrija) }\end{array}$} & fundus & 2 & $\begin{array}{l}\text { pukovnik } \\
\text { pješaštva }\end{array}$ & $\begin{array}{l}\text { uz obrambeni } \\
\text { jarak }\end{array}$ \\
\hline & vrt & 2 & & \\
\hline Mihael Mikulčić (Mikulić, pl.) & fundus & 1 & & Dugi konec \\
\hline Tomo Požgaj & fundus & $11 / 4$ & & Cargovec \\
\hline Ivan Krapinčić & fundus & $1 \frac{1}{4}$ & & Cargovec \\
\hline $\begin{array}{l}\text { ud. Somogy (Adama, pl., } \\
\text { Uršula Hađen) }\end{array}$ & fundus & 1 & & \\
\hline $\begin{array}{l}\text { ud. Strahinje (Ivana, pl., } \\
\text { Katarina Balog) }\end{array}$ & fundus & 1 & & kod Donjih vrata \\
\hline Franjo Kiš, pl. & fundus & 1 & $\begin{array}{l}\text { bilježnik, } \\
\text { podžupan } \\
\text { Varaždinske } \\
\text { županije }\end{array}$ & kod Donjih vrata \\
\hline ud. Mačković & fundus & $1 / 2$ & & \\
\hline \multirow[t]{2}{*}{ Juraj Pavečić (Pavičić), fiscus } & fundus & 1 & $\begin{array}{l}\text { senator, } \\
\text { rizničar, } \\
\text { bilježnik }\end{array}$ & Dugi konec \\
\hline & alodij & 1 & & \\
\hline \multirow[t]{2}{*}{ D: Petar Češković, pl. } & fundus & 2 & & Dugi konec \\
\hline & $\begin{array}{l}\text { fundus, } \\
\text { zapušteni }\end{array}$ & 1 & & \\
\hline Andrija Galeković & fundus & 1 & $\begin{array}{l}\text { oficijal, } \\
\text { rizničar }\end{array}$ & Dugi konec \\
\hline Luka Bočkaj & fundus & 1 & & \\
\hline $\begin{array}{l}\text { ud. Gonzmiller (Konczmiller } \\
\text { Juraja) }\end{array}$ & fundus & 1 & & $\begin{array}{l}\text { Milički konec } \\
\text { (Vrazova ulica, } \\
\text { Ulica braće } \\
\text { Radić) } \\
\end{array}$ \\
\hline \multirow[t]{3}{*}{ Ferdinand (Henrik) Otto } & fundus & $2 \frac{1}{2}$ & plaćenik & \\
\hline & fundus & $1 \frac{1}{2}$ & & \\
\hline & & $31 / 2$ & & sjeverni suburbij \\
\hline Andrija Šoštarić & fundus & $1 / 2$ & & Milički konec \\
\hline Andrija Humer & fundus & 2 & mesar & Dugi konec \\
\hline Ivan Curey & fundus & 1 & & Dugi konec \\
\hline Jakob Petek & fundus & 1 & & \\
\hline
\end{tabular}




\begin{tabular}{|c|c|c|c|c|}
\hline $\begin{array}{l}\text { ud. Hvalec (Mihaela, } \\
\text { Doroteja Smernjak) }\end{array}$ & fundus & 1 & & Vidovski konec \\
\hline Ivan Čanđek & fundus & 2 & mesar & \\
\hline Nikola Đurđan & fundus & 1 & vir communis & \\
\hline ud. Golubić & fundus & 1 & & \\
\hline Ivan Konjarić & fundus & 1 & $\begin{array}{l}\text { mesar, } \\
\text { senator }\end{array}$ & \\
\hline Magda(lena) Trgovčić & fundus & 1 & & \\
\hline Matija Dijaković & fundus & 1 & & Dugi konec \\
\hline Stjepan Špek & fundus & 1 & & Dugi konec \\
\hline Jakob Sokol & fundus & 1 & & \\
\hline $\begin{array}{l}\text { ud. Godrić (Andrije aliter } \\
\text { Mikulić) }\end{array}$ & fundus & 1 & & Dugi konec \\
\hline ud. Leskovar & fundus & 1 & & \\
\hline Ivan Mikolya (Mikula), pl. & fundus & 1 & & \\
\hline \multirow[t]{2}{*}{ fundus Rešetar } & fundus & 1 & & \\
\hline & fundus & 1 & & $\begin{array}{l}\text { u sjevernom } \\
\text { suburbiju }\end{array}$ \\
\hline $\begin{array}{l}\text { ud. Vrban(ić Andrije, Barbara } \\
\text { Kneuch) }\end{array}$ & fundus & $3 / 4$ & & \\
\hline Mihael Mathan? & fundus & 1 & & \\
\hline Marko Posavec & fundus & $3 / 4$ & & \\
\hline fundus Vodopija & fundus & $1 / 2$ & & \\
\hline fundus Svetec & fundus & $1 / 2$ & & \\
\hline gradski alodiji & fundus & 2 & & \\
\hline Matija Horvat & fundus & $1 / 2$ & & \\
\hline Juraj Dorotić & fundus & $1 / 2$ & & \\
\hline ud. Sever (Luke) & fundus & $1 / 2$ & & Dugi konec \\
\hline ud. Ostreš (Jurja) & fundus & $1 / 2$ & mesar & Dugi konec \\
\hline prazno gradsko zemljište & $\begin{array}{l}\text { fundus, } \\
\text { prazni }\end{array}$ & 1 & & \\
\hline Glavač (Mihael, pl.) & fundus & $1 / 2$ & mesar & Dugi konec \\
\hline nasljednici Poljanec & fundus & 2 & & \\
\hline Barbara Klik & fundus & 1 & & \\
\hline zemljište gradsko & fundus & 1 & & \\
\hline Mihael Perec & fundus & 1 & & Dugi konec \\
\hline Blaž Možar & fundus & 2 & $\begin{array}{l}\text { mesar, } \\
\text { cehmeštar, } \\
\text { vir communis }\end{array}$ & \\
\hline
\end{tabular}


VIŠNJA BUREK: Popisi vlasnika gradskih zemljišta u Varaždinu iz druge polovice 17. stoljeća

\begin{tabular}{|c|c|c|c|c|}
\hline ud. Stančić & fundus & 2 & & Dugi konec \\
\hline Marko Zmislia & fundus & 1 & četvrtar & \\
\hline Matija Čemernijak & fundus & $3 / 4$ & & \\
\hline ud. Skočec & fundus & 1 & & Dugi konec \\
\hline fundus Matheak (Stjepan) & fundus & 1 & & Vidovski konec \\
\hline fundus Kollar (Koller Ivan) & fundus & $1 \frac{1}{2}$ & $\begin{array}{l}\text { trubač } \\
\text { tjelesne čete } \\
\text { Varaždinskog } \\
\text { generalata }\end{array}$ & \\
\hline $\begin{array}{l}\text { ud. Škarica (Nikole, Kristijana } \\
\text { Druskoczy) }\end{array}$ & fundus & 2 & ud. senatora & Vidovski konec \\
\hline Dukarić (Grgur) & fundus & 1 & bačvar & \\
\hline nasljednici Mager (Magyer) & fundus & 1 & & \\
\hline Ivan Čižmešija & fundus & 1 & & \\
\hline D: Andrija Ballogh & fundus & 1 & $\begin{array}{l}\text { prokurator, } \\
\text { senator }\end{array}$ & \\
\hline Andrija Krištofić & fundus & 1 & & \\
\hline $\begin{array}{l}\text { Dominus comes Orahoczy } \\
\text { (Stjepan) }\end{array}$ & fundus & 3 & & kod Donjih vrata \\
\hline D: comitissa Erdödy & fundus & 1 & & \\
\hline $\begin{array}{l}\text { ud. Đuraić (Blaža, Magdalena } \\
\text { Dipad) }\end{array}$ & fundus & 2 & ud. kirurga & $\begin{array}{l}\text { uz obrambeni } \\
\text { jarak i Donja } \\
\text { vrata }\end{array}$ \\
\hline Ivan Sabalić & fundus & 1 & $\begin{array}{l}\text { vir communis, } \\
\text { senator }\end{array}$ & Dugi konec \\
\hline $\begin{array}{l}\text { ud. Ocvirek (Stjepana, } \\
\text { Magdalena) }\end{array}$ & fundus & 1 & & Vidovski konec \\
\hline Dominus Petheö (de Gerse) & fundus & 2 & & Vidovski konec \\
\hline Franjo Staniger & fundus & 1 & & Vidovski konec \\
\hline Pavao Benčec & fundus & 1 & & \\
\hline $\begin{array}{l}\text { ud. Goliak (Ivana, Doroteja } \\
\text { Gložić) }\end{array}$ & fundus & 1 & & Vidovski konec \\
\hline Franjo Magier (Magyer), pl. & fundus & 1 & & Vidovski konec \\
\hline Gunketia (Gonkettia Andrija) & fundus & 1 & & \\
\hline Remenar (Luka) & fundus & $3 / 4$ & remenar? & \\
\hline Maszik (Mazek Kristanić) & fundus & 1 & & \\
\hline Juraj Sabolić & fundus & 2 & $\begin{array}{l}\text { upravitelj } \\
\text { ksenodohija }\end{array}$ & Vidovski konec \\
\hline Naslednici Gajanski & fundus & 2 & & Vidovski konec \\
\hline
\end{tabular}




\begin{tabular}{|c|c|c|c|c|}
\hline ud. Videčić & fundus & 1 & & \\
\hline Nikola Stošić & fundus & 1 & $\begin{array}{l}\text { sacrista } \\
\text { parochialis } \\
\text { ecclesiae } \\
\text { Sancti Nicolai }\end{array}$ & \\
\hline Luka Ciganek & fundus & $1 / 2$ & & \\
\hline Čoharek (Čuharek Grgur) & fundus & 1 & & \\
\hline fundus Storga & fundus & 1 & & \\
\hline Mihael Šargač & fundus & 1 & & \\
\hline gradsko zemljište prazno & fundus & 1 & & \\
\hline nasljednici Kovačić & fundus & 1 & & kod Donjih vrata \\
\hline $\begin{array}{l}\text { ud. Tomaško (Juraja, Doroteja } \\
\text { Dijanošić, pl.) }\end{array}$ & fundus & 1 & & \\
\hline Brlek (Andrija) & fundus & $3 / 4$ & & Vidovski konec \\
\hline Marko Brebrović & fundus & 1 & & \\
\hline \multirow[t]{2}{*}{ Hudobec (Ivan) } & fundus & 1 & & \\
\hline & fundus & 2 & & Brodovski konec \\
\hline Petar Malečić & fundus & 1 & vir communis & \\
\hline \multirow[t]{2}{*}{ Tomo Halapia } & fundus & 1 & $\begin{array}{l}\text { senator, } \\
\text { rizničar }\end{array}$ & Vidovski konec \\
\hline & $\begin{array}{l}\text { fundus, } \\
\text { prazni }\end{array}$ & 1 & & \\
\hline Pavao Ilijanić & fundus & 1 & vir communis & $\begin{array}{l}\text { uz obrambeni } \\
\text { jarak }\end{array}$ \\
\hline Juraj Vinković & fundus & 2 & $\begin{array}{l}\text { mesar, } \\
\text { cehmeštar }\end{array}$ & \\
\hline Tomo Jurasić & fundus & 1 & & \\
\hline Andrija Felner & fundus & $3 / 4$ & & \\
\hline nasljednici Šargač & fundus & 1 & & \\
\hline ud. Dramić? & fundus & 1 & & \\
\hline Szabol Martonek & fundus & 1 & krojač? & \\
\hline Urban Pek & fundus & 1 & pekar & \\
\hline Ivan Borković & fundus & 1 & & \\
\hline Juraj Fajfarić (Fajsarić) & fundus & 1 & & kod Donjih vrata \\
\hline Dominus Raffay (Franjo), pl. & fundus & 1 & $\begin{array}{l}\text { contrascriba } \\
\text { varaždinske } \\
\text { tridesetnice }\end{array}$ & \\
\hline Juraj Šegovich & fundus & 1 & & \\
\hline
\end{tabular}


VIŠNJA BUREK: Popisi vlasnika gradskih zemljišta u Varaždinu iz druge polovice 17. stoljeća

\begin{tabular}{|c|c|c|c|c|}
\hline D: Kovachoczy (Juraj), pl. & fundus & 1 & $\begin{array}{l}\text { podsudac } \\
\text { Varaždinske } \\
\text { županije, } \\
\text { homo banalis }\end{array}$ & Vidovski konec \\
\hline Gabriel Jurjević, pl. & fundus & 3 & $\begin{array}{l}\text { bilježnik, } \\
\text { tajnik bana } \\
\text { Nikole } \\
\text { Zrinskog, } \\
\text { tridesetničar }\end{array}$ & Vidovski konec \\
\hline D: Fabriczy & fundus & 1 & & \\
\hline Domus Hymliriana & fundus & 2 & & \\
\hline Domicela Bintersz & fundus & $2 \frac{1}{2}$ & & \\
\hline Nikola Stančić & fundus & 2 & & \\
\hline \multirow[t]{3}{*}{ Nikola Sušić } & fundus & 1 & $\begin{array}{l}\text { vir communis, } \\
\text { tržni } \\
\text { nadzornik }\end{array}$ & $\begin{array}{l}\text { Makarova ulica } \\
\text { (Supilova ulica) }\end{array}$ \\
\hline & $\begin{array}{l}\text { fundus, } \\
\text { prazni }\end{array}$ & 1 & & \\
\hline & alodij & 1 & & $\begin{array}{l}\text { Slopanec (poč. } \\
\text { Optujske ulice) }\end{array}$ \\
\hline D: Špoljarić (Franjo, pl.) & fundus & 1 & tridesetničar & Milički konec \\
\hline D: Stetter (Adam), pl. & fundus & 2 & $\begin{array}{l}\text { plaćenik, } \\
\text { konjanik, } \\
\text { zapovjednik } \\
\text { čete u } \\
\text { Varaždinskom } \\
\text { generalatu }\end{array}$ & Dugi konec \\
\hline \multirow[t]{7}{*}{$\begin{array}{l}\text { ud. Moll (Šimuna, pl., Ana } \\
\text { Marija Jurhan, pl.) }\end{array}$} & $\begin{array}{l}\text { fundus } \\
\text { vertar }\end{array}$ & 1 & $\begin{array}{l}\text { ud. suca } \\
\text { Slavonske } \\
\text { krajine }\end{array}$ & Milički konec \\
\hline & $\begin{array}{l}\text { fundus } \\
\text { Stančević }\end{array}$ & 1 & & \\
\hline & $\begin{array}{l}\text { fundus } \\
\text { Leskovar }\end{array}$ & 1 & & \\
\hline & fundus & $21 / 2$ & & \\
\hline & mlin & & & na Dravici \\
\hline & $\begin{array}{l}\text { Rukelov } \\
\text { mlin }\end{array}$ & & & na Dravici \\
\hline & $\begin{array}{l}\text { fundus uz } \\
\text { mlin }\end{array}$ & 1 & & uz Dravicu \\
\hline
\end{tabular}


Radovi Zavoda za znanstveni rad HAZU Varaždin; br. 31, 2020, str. 31-74

\begin{tabular}{|c|c|c|c|c|}
\hline Juraj vratar & fundus & 1 & vratar & \\
\hline fundus Matak (Stjepan?) & fundus & 1 & & \\
\hline D: Petar Gotal & fundus & 1 & & $\begin{array}{l}\text { uz obrambeni } \\
\text { jarak }\end{array}$ \\
\hline Brestovski (Juraj) & fundus & $3 / 4$ & & \\
\hline $\begin{array}{l}\text { Conko (Zunggo Ivan Antun de } \\
\text { Caprin, pl.) }\end{array}$ & fundus & 3 & $\begin{array}{l}\text { zapovjednik } \\
\text { artiljerije i } \\
\text { topništva }\end{array}$ & $\begin{array}{l}\text { uz obrambeni } \\
\text { jarak }\end{array}$ \\
\hline gospodin general & fundus & 1 & & Milički konec \\
\hline
\end{tabular}

Sjeverni suburbij

\begin{tabular}{|c|c|c|c|c|}
\hline sjeverni suburbij & $\begin{array}{l}\text { vrsta } \\
\text { zemljišta }\end{array}$ & $\begin{array}{l}\text { broj } \\
\text { fundusa }\end{array}$ & $\begin{array}{l}\text { zanimanje, } \\
\text { služba } \\
\text { vlasnika }\end{array}$ & moguće lokacije \\
\hline D: Vlohin (Vlah) & fundus & 4 & & \\
\hline D: Vabliar (Matija) & fundus & 1 & $\begin{array}{l}\text { podsudac } \\
\text { Varaždinske } \\
\text { županije }\end{array}$ & \\
\hline nasljednici Kovač & fundus & 1 & & \\
\hline ud. Peršinović (Stjepana) & fundus & $1 \frac{1}{4}$ & & $\begin{array}{l}\text { Za Svetim } \\
\text { Florijanom }\end{array}$ \\
\hline Pintarić (Elizabeta?) & fundus & $1 / 2$ & & Brodovski konec \\
\hline Ignac Praunsperger & fundus & 1 & trgovac & Slopanec \\
\hline Benčec (Magdalena?) & fundus & 1 & & $\begin{array}{l}\text { Ciglenica } \\
\text { (Trstenjakova } \\
\text { ulice) } \\
\end{array}$ \\
\hline fundus Buszi & fundus & 1 & & \\
\hline Težak (Juraj) & fundus & $1 \frac{1}{2}$ & & Brodovski konec \\
\hline Petar Perhat & fundus & $13 / 4$ & & Dravički konec \\
\hline D: Gereczy (Adam) & fundus & 1 & & \\
\hline Stjepan Mikulić & fundus & 1 & & Dravički konec \\
\hline Juraj Klik, pl. & fundus & $2 \frac{1}{4}$ & $\begin{array}{l}\text { senator, } \\
\text { podsudac } \\
\text { Varaždinske } \\
\text { županije }\end{array}$ & $\begin{array}{l}\text { uz obalu } \\
\text { obrambenog } \\
\text { jarka }\end{array}$ \\
\hline ud. Balangia & fundus & 2 & & \\
\hline
\end{tabular}


VIŠNJA BUREK: Popisi vlasnika gradskih zemljišta u Varaždinu iz druge polovice 17. stoljeća

\begin{tabular}{|c|c|c|c|c|}
\hline Dominus Kuskoczy (Ivan, pl.) & fundus & 1 & $\begin{array}{l}\text { potkapetan } \\
\text { konjice u } \\
\text { Koprivnici, } \\
\text { podsudac } \\
\text { Varaždinske } \\
\text { županije }\end{array}$ & Brodovski konec \\
\hline Praunsperger (Danijel) & alodij & 2 & $\begin{array}{l}\text { trgovac, } \\
\text { poreznik }\end{array}$ & Dravički konec \\
\hline Kollar (Koller Ivan?) & fundus & $1 / 2$ & $\begin{array}{l}\text { trubač } \\
\text { tjelesne čete }\end{array}$ & \\
\hline Grof Petar Keglević & fundus & 2 & & Dravički konec \\
\hline Belcar (Matija) & fundus & 1 & & $\begin{array}{l}\text { uz obrambeni } \\
\text { jarak }\end{array}$ \\
\hline Ivan Gončić & fundus & 2 & & \\
\hline Ivan Valpočić & fundus & 1 & & $\begin{array}{l}\text { s vanjske strane } \\
\text { obrambenog } \\
\text { jarka }\end{array}$ \\
\hline Mihael Benković & fundus & $41 / 4$ & $\begin{array}{l}\text { mesar?, } \\
\text { rizničar }\end{array}$ & Dravički konec \\
\hline D: comes Adam Keglević & fundus & $1 \frac{1}{2}$ & & Dravički konec \\
\hline Matija Keršić & fundus & 1 & & \\
\hline $\begin{array}{l}\text { ud. Slovenčić (Matije, pl., } \\
\text { Uršula Tompos) }\end{array}$ & fundus & 1 & & $\begin{array}{l}\text { Bolfanska ulica } \\
\text { (Trstenjakova } \\
\text { ulica) }\end{array}$ \\
\hline Grgur Czimerman & fundus & 1 & tesar & \\
\hline Valent Pronthaver & fundus & $1 / 2$ & & \\
\hline $\begin{array}{l}\text { Domus Zakmardiana } \\
\text { (isusovci) }\end{array}$ & fundus & $1 / 2$ & & Ciglenica \\
\hline fundus Stanicaricha & fundus & 1 & & \\
\hline Juraj Filmon & fundus & 1 & & \\
\hline ud. Blažinić (Franje) & fundus & 1 & & \\
\hline Marko Tkalec & fundus & $1 / 2$ & & \\
\hline Stjepan Enney & fundus & 1 & & $\begin{array}{l}\text { uz maltu tvrđe } \\
\text { (Trstenjakova } \\
\text { ulica) }\end{array}$ \\
\hline Suzana Rahović & fundus & 1 & & $\begin{array}{l}\text { uz obrambeni } \\
\text { jarak kod } \\
\text { Gornjeg mosta }\end{array}$ \\
\hline
\end{tabular}


Radovi Zavoda za znanstveni rad HAZU Varaždin; br. 31, 2020, str. 31-74

\begin{tabular}{|c|c|c|c|c|}
\hline Pavao Vučinović & fundus & 1 & $\begin{array}{l}\text { tržni } \\
\text { nadzornik, } \\
\text { upravitelj } \\
\text { ksenodohija }\end{array}$ & \\
\hline & alodij & 1 & & \\
\hline nasljednici Krančić & fundus & ? & & $\begin{array}{l}\text { uz nasip ispred } \\
\text { Gornjih vrata }\end{array}$ \\
\hline \multirow[t]{2}{*}{ Martin Krančić } & fundus & 1 & & \\
\hline & alodij & 1 & & \\
\hline Nikola Čižmešija & fundus & 1 & & \\
\hline $\begin{array}{l}\text { Stinglin (Matija Zumer aliter } \\
\text { Stinglin) }\end{array}$ & fundus & 1 & & \\
\hline Fundus Bratovščak & fundus & 1 & & \\
\hline Tobia (Halaszy), sostar & fundus & $1 / 2$ & postolar & \\
\hline fundus Rumek (Ivan) & fundus & 1 & & $\begin{array}{l}\text { uz vrt obitelji } \\
\text { Erdődy (Milički } \\
\text { konec, Vrazova } \\
\text { ulica) }\end{array}$ \\
\hline Ivan Felner Markantun & fundus & $2 \frac{1}{2}$ & & \\
\hline nasljednici Hocheker (Matije) & fundus & 1 & mesar & $\begin{array}{l}\text { uz obrambeni } \\
\text { jarak i Brodovski } \\
\text { konec }\end{array}$ \\
\hline Ivan Kotniak (Kutnjak) & fundus & 1 & vir communis & $\begin{array}{l}\text { Vugerska ulica } \\
\text { (Brodovski } \\
\text { konec, Trenkova } \\
\text { ulica) } \\
\end{array}$ \\
\hline & alodij & 1 & & \\
\hline & vrt & 1 & & \\
\hline Golub (Petar) & fundus & 1 & & $\begin{array}{l}\text { uz obrambeni } \\
\text { jarak i Gornja } \\
\text { vrata }\end{array}$ \\
\hline $\begin{array}{l}\text { prazno zemljište blizu } \\
\text { Gradinščaka }\end{array}$ & fundus & 1 & & Gradinščak \\
\hline Ivanić (Mihael?) & fundus & $1 / 2$ & & \\
\hline fundus Gradinščak & $\begin{array}{l}\text { fundus, } \\
\text { prazni }\end{array}$ & 1 & & \\
\hline fundus Jančec & fundus & $1 / 2$ & & \\
\hline Gombsz (Gombossy Ivan) & fundus & 1 & & \\
\hline Grunček (Blaž) & fundus & 1 & & \\
\hline Simon (Andrija) & fundus & 1 & kovač & \\
\hline
\end{tabular}


VIŠNJA BUREK: Popisi vlasnika gradskih zemljišta u Varaždinu iz druge polovice 17. stoljeća

\begin{tabular}{|c|c|c|c|c|}
\hline Pechi (Ivan, pl.) & fundus & 1 & & Brodovski konec \\
\hline \multirow[t]{2}{*}{ ud. Pipan } & fundus & 1 & & \\
\hline & vrt & 1 & & \\
\hline Jakob Kopiar & fundus & 1 & kopljar & \\
\hline Martin Greblički & fundus & 2 & & Dravički konec \\
\hline Mihael Martinčević & fundus & 1 & vir communis & \\
\hline Martin Radigović & fundus & 1 & & Brodovski konec \\
\hline Prahoničićka & fundus & $1 / 2$ & & \\
\hline Kramar (Bartolomej) & fundus & 1 & trgovac? & Ciglenica \\
\hline fundus Talan & fundus & 1 & & \\
\hline fundus Magier (Stjepan) & $\begin{array}{l}\text { fundus, } \\
\text { zapušteni }\end{array}$ & 1 & & Brodovski konec \\
\hline $\begin{array}{l}\text { ud. Gašperlin (Mihaela, } \\
\text { Lucija Krištofić) }\end{array}$ & fundus & 1 & & $\begin{array}{l}\text { uz vrt Mirka } \\
\text { Erdődyja (Milički } \\
\text { konec, Vrazova } \\
\text { ulica) }\end{array}$ \\
\hline $\begin{array}{l}\text { ud. Groff(in Matije, Uršula } \\
\text { Rozina Baznik) }\end{array}$ & fundus & $1 \frac{1 / 4}{4}$ & ud. stolara & \\
\hline D: Kuskoczy (Petar) & fundus & 2 & $\begin{array}{l}\text { podsudac } \\
\text { Varaždinske } \\
\text { županije, vir } \\
\text { communis }\end{array}$ & $\begin{array}{l}\text { Brodovski konec } \\
\text { kod Krošakovog } \\
\text { zdenca }\end{array}$ \\
\hline ud. Pertichich (Petračić?) & fundus & $1 / 2$ & & \\
\hline Sebastijan Sitar & fundus & 1 & sitar & \\
\hline Pavao Matašić & fundus & 1 & & \\
\hline Florijan Simon & fundus & 1 & & \\
\hline fundus Lončar & fundus & $1 \frac{1}{2}$ & lončar & \\
\hline fundus Geczi & fundus & 1 & & \\
\hline fundus Pintar & fundus & 1 & bačvar & \\
\hline $\begin{array}{l}\text { Nikola Horvat (aliter } \\
\text { Marković) }\end{array}$ & fundus & 1 & & Brodovski konec \\
\hline fundus Briczi & fundus & $1 / 2$ & & \\
\hline fundus Krobot (Stjepan) & fundus & $1 / 2$ & & Brodovski konec \\
\hline Ivan Pojasar & fundus & 1 & pojasar & \\
\hline Nikola bravar & fundus & 1 & bravar & \\
\hline fundus Zlatarek & fundus & 1 & & \\
\hline ud. Mužek & fundus & $1 / 2$ & & \\
\hline Jakob Mlinar & fundus & $1 / 2$ & mlinar & \\
\hline fundus Ignaczy & fundus & 1 & & \\
\hline
\end{tabular}




\begin{tabular}{|c|c|c|c|c|}
\hline ud. Cherni Peter & fundus & 1 & & \\
\hline $\begin{array}{l}\text { fundus Rudnički, sada } \\
\text { gradski }\end{array}$ & fundus & 1 & & Ciglenica \\
\hline Nikola Rokaj & fundus & 1 & & Brodovski konec \\
\hline Harnnay Sostar & fundus & 1 & postolar & \\
\hline Nikola Paljak & fundus & 2 & & Brodovski konec \\
\hline $\begin{array}{l}\text { ud. Lehar (Martina, Coradin } \\
\text { Barbara) }\end{array}$ & fundus & 3 & ud. staklara & Milički konec \\
\hline fundus Drožđek & fundus & $3 / 4$ & & \\
\hline Mihael Vrabec & fundus & 3 & $\begin{array}{l}\text { krojač, } \\
\text { cehmeštar, } \\
\text { senator, } \\
\text { oficijal }\end{array}$ & $\begin{array}{l}\text { s vanjske strane } \\
\text { obrambenog } \\
\text { jarka }\end{array}$ \\
\hline Bratomanić (Mihael, pl.) & fundus & 1 & & \\
\hline $\begin{array}{l}\text { ud. Vadiniay (Ivana, Suzana } \\
\text { Piroš) }\end{array}$ & fundus & 2 & & \\
\hline $\begin{array}{l}\text { ud. Bajz (Nikole, Barbara } \\
\text { Bajz) }\end{array}$ & fundus & 1 & & \\
\hline nasljednici Ranker (Andrije) & fundus & 1 & & \\
\hline Ivan Borković & fundus & $1 \frac{1}{2}$ & & \\
\hline fundus Pojaszar & fundus & $1 / 2$ & pojasar & \\
\hline $\begin{array}{l}\text { ud. Novak (Petra, Jelena } \\
\text { Horvat) }\end{array}$ & fundus & 1 & & Brodovski konec \\
\hline $\begin{array}{l}\text { ud. Kolmar Herbardusa, } \\
\text { baruna }\end{array}$ & fundus & 1 & $\begin{array}{l}\text { ud. konjanika } \\
\text { varaždinske } \\
\text { čete }\end{array}$ & $\begin{array}{l}\text { kuća uz obalu } \\
\text { kanala i } \\
\text { Brodovski konec }\end{array}$ \\
\hline ud. Premužić (Luke) & fundus & 1 & & Brodovski konec \\
\hline Juraj Lovreković & fundus & 1 & & Brodovski konec \\
\hline D: Juraj Krainay & fundus & $3 / 4$ & & Brodovski konec \\
\hline $\begin{array}{l}\text { ud. Pekovica (Matije } \\
\text { Tropinjaka) }\end{array}$ & fundus & 1 & ud. pekara & $\begin{array}{l}\text { uz obrambeni } \\
\text { jarak }\end{array}$ \\
\hline Franjo Široki & fundus & 1 & & \\
\hline Pavao Czikleny & fundus & 1 & krojač & Brodovski konec \\
\hline $\begin{array}{l}\text { Reszek (Supruga kćer Ivana } \\
\text { Cvetkovića) }\end{array}$ & fundus & 1 & & Brodovski konec \\
\hline Petar Tot & fundus & 1 & & Brodovski konec \\
\hline ud. Kerniody & fundus & 1 & & Brodovski konec \\
\hline Nikola Šargač & fundus & 1 & $\begin{array}{l}\text { mesar, } \\
\text { četvrtar }\end{array}$ & \\
\hline
\end{tabular}


VIŠNJA BUREK: Popisi vlasnika gradskih zemljišta u Varaždinu iz druge polovice 17. stoljeća

\begin{tabular}{|c|c|c|c|c|}
\hline Mihael Lovreković & fundus & 1 & & $\begin{array}{l}\text { Na Grabe gdi } \\
\text { zivinszky szciem } \\
\text { sztoy }\end{array}$ \\
\hline Juraj Tomašković & fundus & 1 & & $\begin{array}{l}\text { uz obrambeni } \\
\text { jarak kod } \\
\text { Gornjih vrata }\end{array}$ \\
\hline Juraj Keszl & fundus & 1 & & $\begin{array}{l}\text { uz obrambeni } \\
\text { jarak }\end{array}$ \\
\hline Mihael Saitter & fundus & $1 / 4$ & & \\
\hline Ivan Ileković & fundus & 1 & & $\begin{array}{l}\text { Brodovski konec } \\
\text { u području } \\
\text { Krošakovog } \\
\text { zdenca }\end{array}$ \\
\hline Čakovečki pavlini & fundus & 1 & & $\begin{array}{l}\text { uz obrambeni } \\
\text { jarak kod } \\
\text { Gornjih vrata }\end{array}$ \\
\hline Mihael Heršek & fundus & 2 & & \\
\hline Juraj Mateković & fundus & 1 & lončar & $\begin{array}{l}\text { uz obrambeni } \\
\text { jarak kod } \\
\text { Gornjih vrata }\end{array}$ \\
\hline Juraj Nagy & fundus & 1 & & $\begin{array}{l}\text { kod Gornjih } \\
\text { vrata }\end{array}$ \\
\hline Mihael Koračević & fundus & 1 & & Brodovski konec \\
\hline \multirow[t]{2}{*}{ Luka Hagiek } & fundus & $2 \frac{1}{2}$ & & $\begin{array}{l}\text { kod Gornjih } \\
\text { vrata }\end{array}$ \\
\hline & alodij & 1 & & \\
\hline fundus Bartolić & fundus & 2 & & \\
\hline Luka Bradula & fundus & 1 & & Ciglenica \\
\hline Jakob Saytar (Saitter) & fundus & $1 \frac{1}{2}$ & vojnik & Ciglenica \\
\hline fundus Glasar & fundus & 2 & & Ciglenica \\
\hline gradska zemljišta & fundus & 2 & & \\
\hline franjevaci & fundus & 3 & & \\
\hline fundus Galić & fundus & $1 / 2$ & & \\
\hline
\end{tabular}

